Florida International University FIU Digital Commons

4-23-2003

\title{
Effects of resource limitation on the essential oil production in Ledum palustre ssp decumbens (Ait.) Hultén
}

Tracy A. Baldwin

Florida International University

DOI: $10.25148 /$ etd.FI14050419

Follow this and additional works at: https://digitalcommons.fiu.edu/etd

Part of the Biology Commons

\section{Recommended Citation}

Baldwin, Tracy A., "Effects of resource limitation on the essential oil production in Ledum palustre ssp decumbens (Ait.) Hultén" (2003). FIU Electronic Theses and Dissertations. 1382.

https://digitalcommons.fiu.edu/etd/1382 
FLORIDA INTERNATIONAL UNIVERSITY

Miami, Florida

EFFECTS OF RESOURCE LIMITATION ON THE ESSENTIAL OIL PRODUCTION

IN LEDUM PALUSTRE SSP DECUMBENS (AIT.) HULTÉN

A thesis submitted in partial fulfillment of the

requirements for the degree of

MASTER OF SCIENCE

in

BIOLOGY

by

Tracey A Baldwin

2004 
To: Dean R. Bruce Dunlap

College of Arts and Sciences

This thesis, written by Tracey A. Baldwin, and entitled Effects of Resource Limitation on the Essential Oil Production in Ledum palustre ssp decumbens (Ait.) Hultén, having been approved in respect to style and intellectual content, is referred to you for judgment.

We have read this thesis and recommend that it be approved.
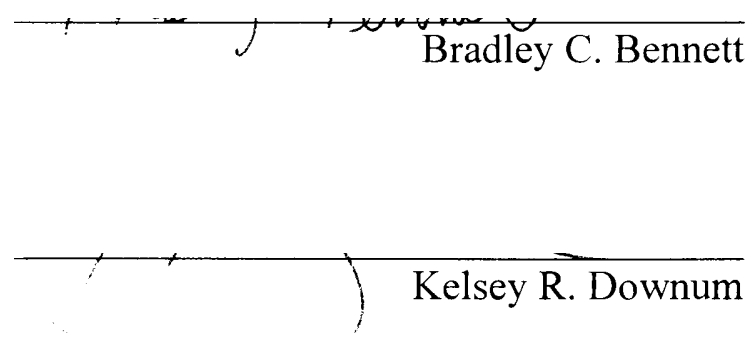

Date of Defense: April 23, 2003

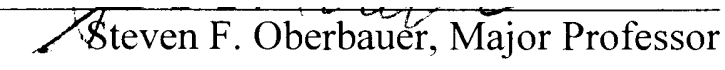

The thesis of Tracey A. Baldwin is approved.

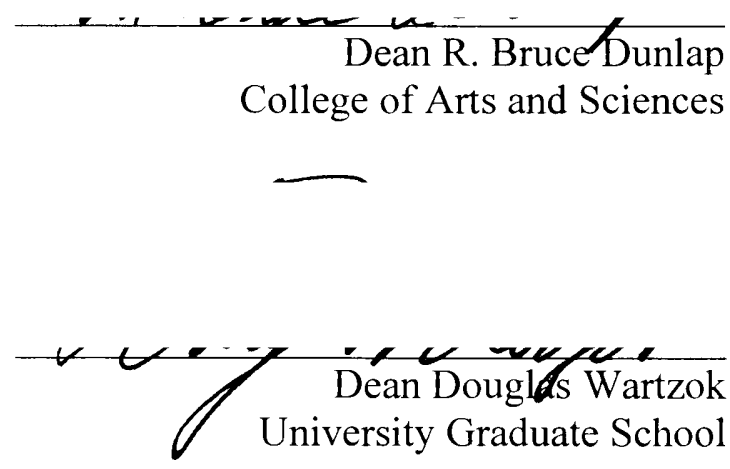

Florida International University, 2004 


\section{DEDICATION}

I dedicate this thesis to my parents. 


\section{ACKNOWLEDGMENTS}

This work is partially based on support from the National Science Foundation grant OPP-9907185. I would like to thank my committee members for their assistance in conducting my research and in writing this thesis. I would also like to thank Dr. Gus Shaver and the staff and researchers of Toolik Field Station for their assistance and accommodation while I was conducting this research. I am especially grateful to the National Science Foundation Research Experiences for Undergraduates Program that gave me the opportunity to begin my study in the Arctic. Thanks to my fellow students in the Oberbauer lab for their assistance at all steps of the thesis process. Also, 1 would like to thank the members of the Seagrass lab, the Department of Chemistry mass spectrometer lab, Ada Ramos, and Dr. Gregory Starr. 


\section{ABSTRACT OF THE THESIS \\ EFFECTS OF RESOURCE LIMITATION ON THE ESSENTIAL OIL PRODUCTION \\ IN LEDUM PALUSTRE SSP DECUMBENS (AlT.) HULTÉN}

by

Tracey A. Baldwin

Florida International University, 2004

Miami, Florida

Professor Steven F. Oberbauer, Major Professor

To understand the relationship between resource limitation and essential oil production of the widely-distributed boreal/arctic shrub, Ledum palustre ssp decumbens, I documented naturally occurring variation of essential oils over a growing season with field collections along a latitudinal transect spanning boreal forest to arctic tundra. Collections from a long-term resource manipulation experiment at a single tundra site served as a means of teasing apart those factors that might be influencing the essential oil production of the species. The essential oil composition varied significantly along the transect in the number of detectable components, but the relationships among resources and essential oil production were complex. In the manipulation experiment, essential oil components varied greatly among the treatments, with significant differences in the qualitative expression of the specific essential oil components. Both studies suggest that future climate changes have the potential for large changes in production and quality of essential oils. 


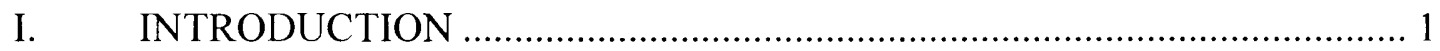

II. VARIATION IN THE ESSENTIAL OIL OF LEDUM PALUSTRE SSP DECUMBENS (AIT.) HULTÉN WITH LATITUDINAL CHANGE.............. 11

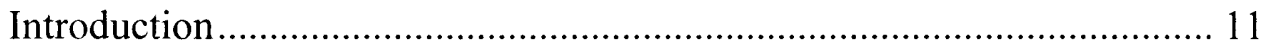

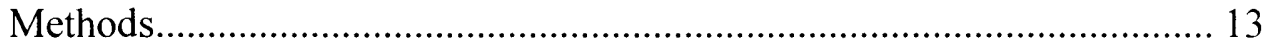

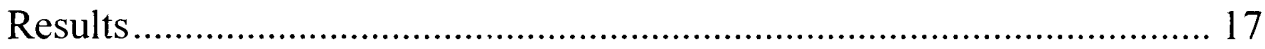

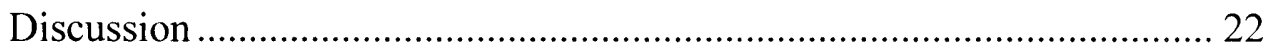

II. THE EFFECT OF LONG TERM RESOURCE MANIPULATION ON THE ESSENTIAL OIL OF LEDUM PALUSTRE SSP DECUMBENS (AIT.)

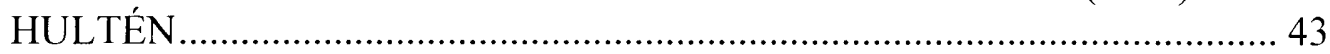

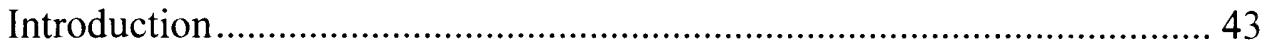

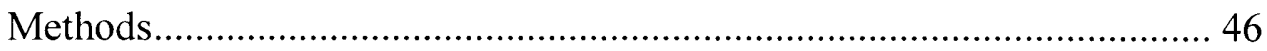

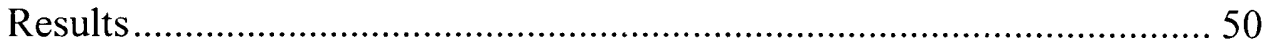

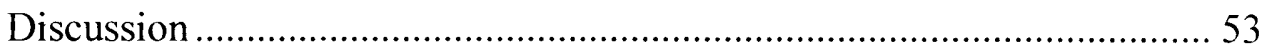

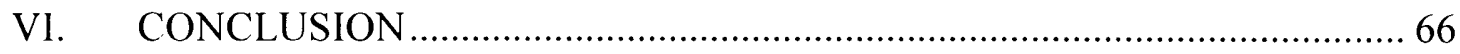

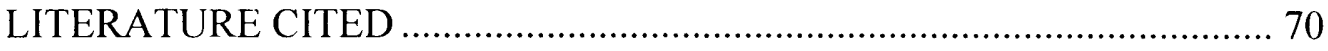




\section{CHAPTER II}

1. Study sites along the latitudinal transect in Alaska....................................... 27

2. Leaf nutrients of Ledum palustre ssp decumbens along the latitudinal gradient by Site

3. Results of two-way ANOVA for Site and Date and for Site and

Phenological stage on measured parameters in this study

4. Percent of essential oil in headspace of Ledum palustre ssp decumbens along latitudinal gradient by Site

5. Percent of each compound in the headspace of Ledum palustre ssp decumbens along latitudinal gradient by Date

6. Percent of each compound in the headspace of Ledum palustre ssp decumbens along latitudinal gradient by phenological stage

\section{CHAPTER III}

1. Leaf tissue nutrients of Ledum palustre ssp decumbens by Treatment 58

2. Physiological status of Ledum palustre ssp decumbens by Treatment 58

3. Results from Two-way ANOVA for effect of treatments on physiological and morphological measurements in Ledum palustre ssp decumbens.

4. Results from Two-way ANOVA for effect of treatments on essential oil variation in Ledum palustre ssp decumbens

5. Variation in the percentage of each compound in the essential oil components in Ledum palustre ssp decumbens by treatment 


\section{LIST OF FIGURES}

\section{CHAPTER II}

I. Map of Alaska showing locations of transect sites 33

2. Diurnal variation in the essential oil of Ledum palustre ssp decumbens collected on Aug 21, 2002 at Toolik Lake

3. Proportional allocation of each compound in the headspace of Ledum palustre ssp decumbens at each collection site

4. Relationship between the quantity of essential oil and the number of compounds in the essential oil of Ledum palustre ssp decumbens

5. Relationship between foliar $\mathrm{C}: \mathrm{N}$ and the quantity and number of compounds in the essential oil of Ledum palustre ssp decumbens.

6. Relationship between foliar $\mathrm{P}$ and the quantity and number of compounds in the essential oil of Ledum palustre ssp decumbens

7. Relationship between the number of compounds and the foliar $\mathrm{C}: \mathrm{N}$ for each site on all collection dates for Ledum palustre ssp decumbens.

8. Relationship between the quantity of essential oil and the foliar $\mathrm{C}: \mathrm{N}$ for each site on all collection dates for Ledum palustre ssp decumbens.

9. Relationship between the number of compounds and the foliar P for each site on all collection dates for Ledum palustre ssp decumbens.

10. Relationship between the quantity of essential oil and the foliar $P$ for each site on all collection dates for Ledum palustre ssp decumbens

\section{CHAPTER III}

1. Site experimental layout for the Arctic Long Term Ecological Research Project at Toolik Lake, AK depicting sampling locations

2. Average leaf size area and leaf-level light availability of Ledum palustre ssp decumbens by treatment 
3. Total quantity of essential oil detectable in the headspace of samples of Ledum palustre ssp decumbens by treatment............................................... 63

4. Percentage of each compound in the total essential oil of samples of Ledum

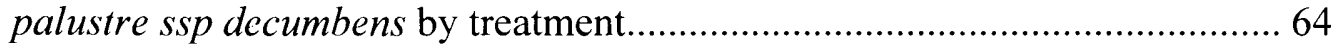

5. Representation of the relative percent of each compound in the essential oil of Ledum palustre ssp decumbens by treatment 


\section{CHAPTER I}

\section{INTRODUCTION}

\section{Resource Availability and Secondary Compound Production}

Resource limitation of physiological processes represents a fundamental constraint on the growth and development of individual species and therefore community and ecosystem processes. Many studies have attempted to tease apart those factors that regulate the allocation of resources to different physiological requirements (Loomis 1932, Larsson I986, Lorio 1986, Rhoumaki 1996, Keinanen 1999, Zavala 2001). One of these requirements is the production of secondary compounds that act to defend against a variety of damages from herbivory, pathogens, UV radiation, and other external factors. Nevertheless, the partitioning of resources and the role of resource limitation in the production of secondary compounds is still under debate.

The production of secondary compounds such as essential oils has been historically considered from two contrasting viewpoints. One suggests that secondary compound production results from the adaptive allocation of photosynthate at the expense of growth. The other suggests that secondary compound production is the result of an obligate metabolism within some other constraint in the plant such as genetics or a byproduct of primary metabolism (Hanover 1966). In either case, environment directly affects the production of secondary compounds through induction or suppression of specific genes, the result of resource limitation and availability, or through the induction by other environmentally mediated factors such as herbivory. The production of secondary compounds therefore varies as a response to genotypic and environmental variation. 
Two hypotheses have been proposed to explain different aspects of the allocation

of resources to secondary compounds. These hypotheses are (1) the resource availability hypothesis, and (2) the growth-differentiation balance hypothesis. These hypotheses provide the theoretical context for the evaluation of the role of resource limitation in secondary compound production. They attempt to explain the environmental and inducible production of these compounds, but do not consider genetic or intrinsic compound production.

The resource availability hypothesis (Bryant et. al. 1985) predicts a decline in allocation to carbon-based secondary metabolites when carbon gain is limited, as during periods of low light (Bryant et. al. 1985, Bryant 1987). This prediction is based on the premise that plants attempt to maintain an optimal carbon to nutrient balance. For example, among terpenoid-producing herbs, high light levels (without additional resource supplementation) stimulate the production of monoterpenes (Zavala 2001). In young willow plants (Salix dasyclados) placed in low light and low nitrogen, Larsson and coauthors (1986) found that the levels of phenolics (carbon-based compounds) were three times lower than those of the controls or low nitrogen plants. These results provide evidence that a reduced carbon source and a decrease in photosynthesis results in lower concentrations of carbon-based secondary compounds. In other words, the quantity of carbon-based secondary compounds will decrease as light levels decrease or upon an alteration of the carbon: nitrogen: phosphorus ratio.

The growth-differentiation balance (GDB) hypothesis (Loomis 1932, Lorio 1986, Herms 1992) predicts how plants will balance allocation between differentiation- related processes and growth-related processes over a range of resource conditions. The GDB 
hypothesis makes the following predictions: (1) plants experiencing low levels of resources will be limited in both photosynthetic ability and growth resulting in both low rates of biomass increase and low production of secondary metabolites (Herms 1992). (2) Plants experiencing intermediate resource availability will have high concentrations of secondary metabolites but an intermediate level of growth relative to plants experiencing the other ends of the resource spectra (Loomis 1932). There is inhibition of growth by small shortages of resources, but net photosynthesis is less sensitive to the same resource limitations (Chapin 1980). Secondary metabolites will accumulate in plants that are not photosynthesizing at high levels but are also experiencing growth inhibition resulting from resource limitations (Wilkens I996). (3) Finally, plants that are not limited by resources will be photosynthesizing at their highest rates and therefore will allocate the majority of energy to growth (Loomis 1932, Herms 1992). If a plant is resource limited then the level of limitation determines the amount of energy allocated to the development of secondary compounds.

These hypotheses provide a framework for understanding environmentally mediated variability found in secondary compound production. However, it is important to note that genotypic plasticity within species will also factor in the expression of secondary compounds. A plant is genetically constrained to a certain range of secondary compound production despite environmental variation. Resource availability does not affect this plasticity but is a potential factor in secondary compound variation within this range. The literature is extensive on the variation in secondary compound production (Zangerl 1986, Marquis 1992, Kroicheva et. al. 1998, Keinanen et. al. 1999, Hamilton et. al. 2000), but there is also great variability in the response of different species to external 
factors. For example, the furanocoumarins found in Pastinaca sativa respond most to induced damage, followed by genotypic variation, and finally to light and nutrient variation (Zangerl 1986, Hamilton et. al. 2000). Alternatively, the tannin and total phenolic composition of Betula pubescens ssp tortuosa is most affected by fertilization and shade, then by genotype, and finally by damage (Ruohomaki et. al. 1996). This variation in causality of secondary compound production has led to many debates over the validity of these hypotheses. These hypotheses are presented here in combination with genetic constraints because they explain different aspects of resource allocation to secondary compounds that collectively may help explain factors regulating essential oil production.

\section{Climate Change and Essential Oils}

Arctic ecosystems are likely to be among the ecosystems most affected by changing climatic conditions. General Circulation Models (GCMs) predict changes in factors strongly affecting ecosystem processes, specifically increases up to $5.2^{\circ} \mathrm{C}$ in annual global temperature and a I5\% global annual precipitation increase (Boer et. al. 1990). These changes are expected to be magnified in the arctic region with a $2-2.4$ times the annual global value increase in temperature and a $5-10 \%$ increase in addition to the annual precipitation increase (Houghton et. al. 2001). These changes will affect other environmental factors such as nutrient availability, season length and soil moisture in the Arctic (Nadelhoffer 1997). While considerable research has focused on the effects on plant production and nutrient cycling, the effects of climate change on aspects of secondary compounds have been largely neglected. These climate changes are likely to result in an alteration, both qualitatively and quantitatively, in the production of 
secondary compounds, affecting the economic uses and ecological interactions of specific species. Here I present work that aims to increase the understanding of the interaction between resource availability and secondary compound production in an ecological and medicinally important plant. I interpret the findings from both ecological and economic viewpoints and speculate on possible effects of climate change on ecological interactions.

\section{Study Species}

I addressed the role of resource limitation in the production of essential oil by Ledum palustre ssp decumbens (Ait.) Hultén. Economically, the shrub is an important food and medicinal source for circumpolar native peoples. The essential oil of the shrub has uses in non-indigenous medical practice as a homeopathic remedy of puncture wounds (especially spider poisonings) and historically in indigenous practices as a treatment for coughs, colds and pulmonary disorders. Current use by native people in Alaska is as a tea rich in Vitamin $\mathrm{C}$ and as a flavoring. However, L. palustre ssp decumbens is nildly toxic due to the sesquiterpene ledol, a substance that can produce cramps, paralysis, heart palpitations, or a condition referred to as Ledum rheumatism (Walker 1984, Russels 1991).

Ecologically, L. palustre ssp decumbens is an important species with a circumpolar distribution, representing up to $50 \%$ of vegetative cover in wet shrub tundra and as a dominant understory shrub in boreal forest. Belleau and Collin (1993) identified multiple terpenoid compounds in the essential oil of Ledum groenlandicum (Ledum palustre ssp groenlandicum). Terpenoid compounds are known to act as allelopathic agents. Inderjit and Malik (1997) identified a change in black spruce (Picea mariana) seedling growth with changing soil chemistry resulting from additions of Ledum palustre 
ssp groenlandicum leaves, suggesting an allelopathic interaction. The importance of $L$. palustre ssp decumbens as an allelopathic factor in boreal forest will increase as the timberline encroaches in elevation and latitude towards arctic tundra with increasing global temperatures (Sveinbjornsson 1992). In a simulated environmental change experiment, leaf emergence and flowering in L. palustre (unspecified subspecies) occurred earlier when the temperature was increased $1.3^{\circ} \mathrm{C}$ over the growing season (Suzuki and Kudo, 1997). This finding suggests a temporal change in the expression of different secondary compounds with increased global temperature that might result in a change in the allelopathic effects of L. palustre ssp decumbens if the expression of the allelopathic compounds in the essential oil occurs earlier than the establishment of competitor seedlings.

Ledum palustre is an evergreen, prostrate shrub that retains its leaves for 2-3 years with a flush of new leaves in early July (Shaver 1983, Chapin 1995). The plant is one of the few winter food sources for snowshoe hares. There are two taxa of $L$. palustre in Alaska: Ledum palustre subsp. decumbens (Aiton) Hultén and Ledum palustre subsp. groenlandicum (Oeder) Hultén. The two taxa have been treated both as different species within the genus Ledum or as subspecies of Ledum palustre. Hultén (1968) treated the two as subspecies due to geographic populations that integrate clinally on contact with the presence of interbreeding hybrids. Work by Saville (1969) separated the two as different species based on significant morphological differences, lack of clinal integration and differences in rust parasites. Specifically, Chrysomyxa ledi var. ledi on L. palustre ssp decumbens is morphologically distinct from C. ledi var. groenlandici that occurs on L. palustre ssp groenlandicum. Karlin and Bliss (1983) also support the distinctiveness of 
the two based on germination ecology studies. Kron and Judd (1990) have identified the two as distinct species, but place the entire genus within Rhododendron based on cladistic analysis. They proposed a name change for L. palustre ssp groenlandicum to Rhododendron groenlandicum (Oeder) Kron \& Judd and suggested the name Rhododendron tomentosum Harmaja ssp subarcticum (Harmaja) G. Wallace be used for subspecies decumbens. However, uncertainty remains regarding the placement and divisions of the genus Ledum due to varying characteristics such as chromosomal numbers and plant distributions. These two have been referred to as "strictly sympatric" (Saville 1969) in boreal forest, but only L. decumbens has been observed beyond the Taiga-Tundra boundary. Several collections of Ledum from Eastern Alaska are considered hybrids between $L$. groenlandicum and $L$. decumbens with potential backbreeding to parents (Dalgaard and Fredskild 1993), exemplifying the confusion in the literature regarding the taxonomy of the two populations. The debate is further confounded by the lack of any obvious interbreeding due to difference in time of anthesis or the possibility of $L$. palustre ssp decumbens existing as a tetraploid $(2 \mathrm{n}=56)$ and L.palustre ssp groenlandicum as a diploid $(2 \mathrm{n}=26)$. The two subspecies differ in morphology with varying stamen number, average stature, and other morphological characteristics, yet their economic usage is identical. Because the taxonomic situation is still unclear, 1 have chosen to refer to the two as subspecies following the nomenclature presented by Hultén (1968) that is used in most of the ecological literature: Ledum palustre L. ssp groenlandicum (Oeder) Hultén and Ledum palustre ssp decumbens (Ait.) Hultén. 


\section{Essential Oils}

Volatile, essential, or ethereal oils are defined as aromatic volatile substances of an oily nature. These oils are located in all parts of a plant and are chiefly composed of terpenes, a family of hydrocarbon-based molecules. Terpenes are characteristically chains or simple cyclic compounds composed of 10 to 15 -carbon molecules. The production of essential oil compounds is referred to as secondary metabolism because the pathway is not a function of primary metabolism. Specifically these compounds contain olefinic terpenes (such as myrcene), alicyclic monoterpenes ( $\alpha$ pinene), sesquiterpenes (citronella), phenols (thymol), alcohols (terpinol), and aldehydes.

Essential oil composition varies both spatially and temporally. Powell and Adams (1973) documented seasonality in the composition of volatile terpenes in Juniperus scopulorum. Specifically, the observed variation was negatively correlated with growth with a significant decline during the winter and a significant increase in spring and summer. Additional work by Adams and Hagerman (1977) documented volatile essential oil variation in Juniperus scopulorum associated with the diurnal cycle; the volatile essential oil differed significantly between collections at 9 AM and 6 PM, perhaps as a result of temperature variation (Tatro et. al. 1973). Variation in ambient temperatures will affect the composition of volatile compounds, as increasing temperature will result in the volatilization and therefore loss of key components. Alternatively, this variation is possibly a result of production of terpene hydrocarbons, alcohols and aldehydes acting as

precursors to sesquiterpenes occurring later in the day (Adams and Hagerman 1977). The essential oil of L. palustre ssp decumbens varies throughout the growing season with changes in composition associated with changing phenological stages (Belleau and Collin 
(1993). Part of this phenological variation is the result of variation in leaf age. Work by

Coley and coauthors (1985) presented ideas on the variation in essential oil composition with leaf age and how that variability relates to herbivore defense. At leaf flushing, the presence of young leaves will warrant more defensive secondary compounds as physical defenses have yet to form. Reichardt and coauthors (1990) identified germacrone as the primary defensive compound against snowshoe hare herbivory. Belleau and Collin (1993) noted an increase in germacrone concentration before snow accumulation in the fall, and speculate this is timed to coincide with increasing herbivory pressure (Bryant 1985). Therefore, temporal variation in the quantitative expression of essential oils is likely the result of the interaction between diurnal and seasonal patterns of plant processes.

Spatial variation in essential oil composition is illustrated by the presence of specific chemotypes. For example, the essential oil of $L$. palustre from Finland is primarily composed of the monoterpene mycrene and the sesquiterpenes palustrol and ledol, while samples from Alaska predominantly contain the sesquiterpenes germacrone (Evstatova et. al. 1981) and ledol (Tattje and Bos 1981). Whether variation in essential oil expression is based on taxonomic relationships or resource availability is unclear. Kudo (1995) found a higher $\mathrm{N}$ concentration, longer life span, smaller leaf size, and a smaller specific leaf area for L. palustre in more northern latitudes. These findings suggest that variation in climate and resources will result in variation in the essential oil composition. Correspondingly, the variation in the essential oil composition resulting from changing climate conditions might affect the utilization of the herb by native peoples as well as the ecological interactions of the shrub. 


\section{Research Approach}

I used two approaches to evaluate the variation in essential oil composition in response to resource availability. First, I determined the naturally occurring variation along a latitudinal transect in north central Alaska. This transect represents different resource availability, plant community types, climates, and a natural intrinsic variability within the range of L. palustre ssp decumbens. The transect length was sufficient to warrant concern regarding complicating effects of diurnal variation on the essential oil expression. Therefore, I conducted preliminary studies to evaluate diurnal variation in essential oil. Second, I collected samples from a long-term resource manipulation experiment to determine the relationship between availability of specific resources and essential oil production and composition. The second experiment functioned as a controlled manipulation to isolate different factors that might be affecting essential oil production in natural environments. Both experiments served as a means of determining the potential effects of global climate change on the essential oil production of L. palustre ssp decumbens. This thesis is written with four chapters: an introduction, two chapters designed as separate journal articles based on the two approaches above, and then a concluding chapter synthesizing the entire project. 


\title{
CHAPTER II
}

\author{
VARIATION IN THE ESSENTIAL OIL OF LEDUM PALUSTRE SSP \\ DECUMBENS (ALT.) HULTÉN ALONG A LATITUDINAL TRANSECT \\ INTRODUCTION
}

Resource limitations of physiological processes represent a fundamental constraint on the growth and development of individual plant species and therefore community and ecosystem processes. Many studies have attempted to tease apart those factors that regulate the allocation of resources to different physiological requirements (Loomis 1932, Larsson 1986, Lorio 1986, Rhoumaki 1996, Keinanen 1999, Zavala 2001). One of these requirements is production of secondary compounds that defend against a variety of damage from herbivory, pathogens, UV radiation, and other factors. Nevertheless, the partitioning of resources and the role of resource limitation in the production of secondary compounds is still debated.

Changes in global climate will strongly affect environmental factors such as air and soil temperatures, cloudiness, and precipitation, particularly in arctic and boreal regions where such changes are expected to be greatest (Maxwell 2001). These changes in turn will affect availability of important resources for plants such as degree days, light, soil moisture, soil nutrients, and soil oxygen that will potentially result in large alterations, both qualitatively and quantitatively, in the production of secondary compounds. Such changes in secondary compound production will likely affect ecological interactions among species present in both taiga and tundra, including humans.

The objective of this project was to test the effect of resource availability on essential oil production of an important boreal and arctic plant, Ledum palustre ssp 
decumbens (Ait.) Hultén. Essential oils are carbon-based secondary compound consisting of terpenes. Essential oil composition has been shown to vary both temporally (diurnally, seasonally) and spatially. Powell and Adams (1973) documented seasonality in the composition of volatile terpenes in Juniperus scopulorum, and Adams and Hagerman (1977) showed volatile essential oil variation was associated with the diurnal cycle in the same species. Spatial variation in essential oil composition and amount is represented in different chemotypes. For example, the essential oil of L. palustre from Finland is primarily composed of the monoterpenes mycrene, palustrol, and ledol, while samples from Alaska predominantly contain the sesquiterpenes germacrone (Evstatova 1981) and ledol (Tattje and Bos, 1981). Whether chemotypes represent variation in essential oil expression based on either taxonomic relationships or resource availability is unclear.

As an initial documentation of variation in essential oil in relation to natural gradients in important resources, I examined essential oil production of $L$. palustre ssp decumbens across a $500 \mathrm{~km} \mathrm{N-S} \mathrm{transect} \mathrm{spanning} \mathrm{interior} \mathrm{boreal} \mathrm{forest} \mathrm{to} \mathrm{arctic} \mathrm{tundra}$ in Alaska. The transect represented strong gradients in temperature, light, nutrient availability, and plant community composition.

\section{Study Species}

Ledum palustre ssp decumbens is a dwarf evergreen shrub in the Ericaceae with a circumpolar distribution. Ecologically, L. palustre ssp decumbens is an important species representing up to $50 \%$ of vegetative cover in wet shrub tundra and as a dominant understory shrub in boreal forest. Ledum represents one of few winter food sources for snowshoe hares. Work by Belleau and Collin (1993) identified multiple terpenoid compounds in the essential oil of a closely-related species (or subspecies) Ledum 
groenlandicum (Ledum palustre ssp groenlandicum). Terpenoid compounds are known to act as allelopathic agents. Inderjit and Malik (1997) identified a change in black spruce (Picea mariana) seedling growth with changing soil chemistry resulting from additions of Ledum palustre ssp groenlandicum leaves, also suggesting an allelopathic interaction. The importance of allelopathic compounds of L. palustre ssp decumbens in boreal forest may increase as treeline encroaches in elevation and latitude towards arctic tundra with increasing global temperatures.

Economically, L. palustre ssp. decumbens is commonly used by circumpolar peoples. The essential oil of the shrub has uses in nonindigenous medicinal practice as a homeopathic remedy of puncture wounds (especially spider poisonings) and historically in indigenous practices as a treatment for coughs, colds, bronchial, and pulmonary disorders. Current use by indigenous people in Alaska is primarily as a beverage flavoring with historical medicinal use (Von Kleist III, personal communication).

\section{METHODS}

\section{Study Sites}

I sampled five sites along a latitudinal gradient from 65.34 to $69.19^{\circ} \mathrm{N}$. The gradient originated $112 \mathrm{~km}$ north of Fairbanks, Alaska to $112 \mathrm{~km}$ north of Toolik Field Station (Figure 1). The five sites were selected based solely on linear distance and represented variation in community type, resource availability, temperature, altitude, and latitude (Table 1). Each site was approximately $1 \mathrm{~km}$ off the road to reduce any road effects (Moorhead 1996) on the study plants.

The latitudinal transect included tussock tundra and boreal forest sites separated by the Brooks mountain range in central Alaska. The dominant vegetation at the sites 
north of the mountain range was tussock tundra with Eriophorum vaginatum, Ledum palustre ssp decumbens, and Betula nana as codominant species. Sites south of the Brooks Range were primarily taiga with tundra at higher elevations. The vegetation south of the mountain range was dominated by Picea glauca, Picea mariana, and Betula papyrifera in the upper canopy and L. palustre ssp groenlandicum and L. palustre ssp decumbens in the lower canopy. Both L. palustre ssp groenlandicum and L. palustre ssp decumbens were present as understory plants in forests that were predominantly white or black spruce (Picea glauca or Picea mariana). The mountain range serves as a barrier for both tree line movement and arctic air masses. The form of Ledum present is strongly elevation dependant with $L$. palustre ssp decumbens occurring on north-facing slopes, higher elevations, and north of the Yukon River, and Ledum palustre ssp groenlandicum occurring on the south side of the Brooks Range at lower elevations. The occurrence of permafrost is likely important for the distribution of the different forms of Ledum through its effects on soil depth and ecosystem type. The growing season in the region is typically mid May to early September; at Toolik Lake, AK, the growing season mean temperature is $7^{\circ} \mathrm{C}$.

\section{Sample Collection}

I sampled at each site approximately every 2 wk over the course of the growing season (June 13 to August 18, 2002). This sampling design resulted in 20 total collections (five sites $\mathrm{x}$ four collections). Sites were sampled repeatedly to account for variation in the phenological stages along the transect. For example, the farthest north site flowered 2 wk after the farthest south site. Previous studies have determined qualitative differences in the essential oil based on phenological stages (Belleau 1993). A sampling period of 
approximately every $2 \mathrm{wk}$ was adopted to coincide with the movement from one phenological stage to another. At each collection, the aerial parts of five individuats of $L$. palustre ssp decumbens were collected from within a $25 \mathrm{~m}^{2}$ area at each site. A sample area greater than $10 \mathrm{~m}^{2}$ was selected to increase the potential of collecting genetically different individuals at each site. Calmes and Zasada (1982) established the tendency towards vegetative reproduction of this species and suggested that most individuals of this species within $10 \mathrm{~m}^{2}$ are genetic clones. All samples were immediately placed on ice until they were frozen at $-20^{\circ} \mathrm{C}$ or below in a freezer. Each individual was separated into two different samples, with one portion containing leaves and stems in a zip bag stored at $-20{ }^{\circ} \mathrm{C}$, and the other separated into leaves and dried for $48 \mathrm{~h}$ at $70{ }^{\circ} \mathrm{C}$ for nutrient analysis.

The location of each site was recorded using a handheld GPS unit (Magellan, San Dimas, CA. Temperature and light availability at plant level were also measured at each site during sampling using a copper-constantan thermocouple and a calibrated GaAsP photodiode using a high-resolution multimeter (Tenma, Springboro, $\mathrm{OH}$ ).

\section{Diurnal Cycle Collection}

Adams and Hagerman (1977) suggested that essential oil content varies based on diurnal fluctuations in temperature and light and possibly diurnal patterns of physiological processes. To determine diurnal variation in the expression of secondary compounds in Ledum, I collected six replicates from a single large individual plant at Toolik Lake at 4 -h intervals over a $24 \mathrm{~h}$ period. All samples were kept at $-20^{\circ} \mathrm{C}$ or below until extraction and analysis. 


\section{Plant Nutrient Composition}

Plant nutrient composition was measured for the macronutrients that are most limiting in the distribution range of the study species, $\mathrm{N}$ and $\mathrm{P}$. The $\mathrm{C}: \mathrm{N}$ ratio in dried leaf samples were measured using an elemental analyzer (Carlo Erba, Valencia, CA). Percent phosphorus was measured using a molybdate antimony volumetric technique. Samples were weighed, ashed at $800^{\circ} \mathrm{C}$ for $6 \mathrm{~h}$ in a muffle furnace, acidified, and reacted with ammonium molybdate and antimony. The resulting solution was measured using a spectrophotometer (Shimadzu, Columbia, MD).

\section{Essential Oil Analysis}

Essential oil analysis was accomplished using a dynamic headspace sampling technique. To determine the amount of the different components, $0.2100 \mathrm{~g}$ of a representative leaf sample was placed in a 10-ml headspace autosampler vial. No effort was placed on selecting a specific leaf age or quality and the resulting samples contained a mixture of both new and old leaves representative of the plant at the time of collection. Samples were heated to $80{ }^{\circ} \mathrm{C}$ for 5 min to release volatile compounds and stabilize the temperature. A $25 \mu$ l sample of headspace was extracted and analyzed using a gas chromatograph with an attached mass spectrometer (Hewlett Packard 5973 MSD, 0.25 $\mu \mathrm{m}, \mathrm{DB}-5$ capillary column). This headspace technique allowed for a rapid identification and subsequent quantification of the major components in the essential oil while also minimizing the adulteration of the compounds that occurs in other extraction methods. Components were measured using peak area analysis. The compounds that were detectable by our instrument were qualitatively determined and the most prevalent of those compounds were analyzed quantitatively to determine variation among samples. 
These compounds were $\alpha$ - pinene, $\beta$ - pinene, cymene, camphene, $\gamma$ - terpenol, unknown monoterpene $1, \alpha$-phellandrene, allocymene, unknown sesquiterpene 2 , sabinene, unknown sesquiterpene 3 and terpinene.

\section{Data Analysis}

Data were analyzed with the SPSS statistical package (SPSS, Inc, Chicago, IL) using principle component analysis (PCA), analysis of variance (ANOVA), and multivariate analysis of variance (MANOVA). Principle component analysis (PCA) was conducted to determine the relationships among the individual essential oil components. Since no clear groupings could be isolated, the compounds were analyzed individually. Analysis of variance (ANOVA) was performed after testing for normality and transforming when necessary. The effect of site, collection date, phenological stage at the time of collection and their interactions were tested with the number and quantity of essential oil components to eliminate blurring of the two independent effects. $\mathrm{C}: \mathrm{N}$ ratio and percent $\mathrm{P}$ were analyzed as covariates to evaluate the relationships between nutrient allocation, site and date on the variation in the essential oil. Correlation analysis was conducted to determine the relationship between the quantity of essential oil and the number of compounds in the essential oil as well as the relationship between the essential oil and the amount of nutrients in the plant.

\section{RESULTS}

Variation in Nutrient Composition: $C: N$

Nutrient composition varied significantly among the five sites, over the growing season, and with changing phenological stage (Table 2). The $\mathrm{C}: \mathrm{N}$ ratio was highest at Finger Mountain and lowest at Toolik Lake $(\mathrm{F}=13.924, \mathrm{P}<0.001)$. The $\mathrm{C}: \mathrm{N}$ ratio changed 
throughout the season with the highest ratio occurring in plants collected on July 21 and the lowest in those collected on June $13(\mathrm{~F}=5.109, \mathrm{P}=0.003)$. The ratio steadily increased as the season progressed until July 21 and then decreased just as steadily between July 21 and Aug 21. The average phenological stage of the sites also affected the C:N ratio, with plants in flower having the lowest $\mathrm{C}: \mathrm{N}$ and plants with senescing flowers having the highest $(\mathrm{F}=7.859, \mathrm{P}<0.001)$.

The percent phosphorus in the leaves was also lowest at Finger Mountain but was highest at the Franklin Bluffs (Table 2, $\mathrm{F}=5.320, \mathrm{P}=0.001$ ). Seasonal variation in the percent $\mathrm{P}$ was not significant $(\mathrm{F}=1.871, \mathrm{P}=0.140)$. Percent $\mathrm{P}$ was highest when the plants were in flower and lowest when the flowers were senescing $(\mathrm{F}=2.673, \mathrm{P}=0.028)$.

There was a negative relationship between the percent $\mathrm{P}$ in the leaves and $\mathrm{C}: \mathrm{N}$ (Pearson correlation $=-.716, \mathrm{p}<.001)$ across all collection sites and times (Table 2).

\section{Diurnal Cycle Variation}

Both the number of compounds and the quantity of essential oil in L. palustre ssp decumbens varied with time of day (Figure 2). However, the time period of interest during which samples were collected along the transect was from 11:00 to $1900 \mathrm{hr}$. Analysis within this time frame revealed an effect of time on the number of compounds $(\mathrm{t}=9.707, \mathrm{P}=0.010, \mathrm{df}=3)$ but not on the overall quantity of oil $(\mathrm{t}=3.484, \mathrm{P}=0.073, \mathrm{df}=3)$. Therefore, diurnal variation must be taken into account when interpreting the variation detected along the transect. 
The total quantity of essential oil in the headspace of L. palustre ssp decumbens varied by site, but not by date or phenological stage (Table 3). Plants at Livengood had the largest quantity of essential oil and those at Toolik Lake had the lowest $(F=5.284$, $\mathrm{P}=0.001$ ). The quantity of essential oil was highest when the plants were in flower and lowest before flowering (initially snowfree and in bud had the same amount of essential oil) $(\mathrm{F}=2.965, \mathrm{P}=0.017)$.

Leaves of Ledum emitted an average of 19 compounds within the detectable limits of the instrument. The variation in the number of components was affected by site and date as well as phenological stage (Table 3). All sites differed from each other in the number of compounds except Finger Mountain and Franklin Bluffs, both of which had 20 (Table 4). Plants at Toolik Lake had the lowest mean number of detectable components (11). Plants at Livengood had the highest $(26, \mathrm{~F}=27.409, \mathrm{P}<0.001)$. Each site was unique in the number of detectable compounds over the season (Table 4). Without the inclusion of site in the analyses, all dates except June 13 and July 1 were different (Table 5). June 13 had the same mean number of compounds as July 1 (22), and then the number steadily declined to nearly half as many detectable compounds on August $16(12, \mathrm{~F}=26.333$, $\mathrm{P}<0.001)$. When the number of detectable compounds was tested for the effect of phenological stage, statistical differences were also found (Table 6). More compounds were present when the plants were in flower (25) than when samples were initially snow free (16), in bud (18), with senesced flowers (17), expanding capsules (17), or with capsules dehisced (14) $(\mathrm{F}=7.080, \mathrm{P}<0.001)$. A difference was seen only when the plants were in flower $(\mathrm{P}<0.001)$. As the plants progressed phenologically, Livengood, Finger 
Mountain, and Toolik Lake all decreased in the number of compounds while both Coldfoot and Franklin Bluffs initially increased and then decreased the number of compounds $(\mathrm{F}=5.539, \mathrm{P}<0.001)$.

Twelve individual compounds were identified as the major components of the volatilized essential oil of $L$. palustre ssp decumbens along the sampled transect. Of these 12 compounds, several were not uniformly present at all dates and all sites, but were represented in large enough quantities when present to warrant inclusion as major components (Figure 3). A-phellandrene was present at all sites for the first two collection dates but was undetectable on July 31 and Aug 16. Unknown 3 was also not present at any of the sites on July 31 and Aug 16 but was present on June 13 and July 01 . Cymene is the major component of the headspace representing up to $86 \%$ of the volatilized compounds in the collections. ANOVA revealed that the composition of the essential oil varied along the latitudinal transect as a function of site, date of collection and the interaction between site and collection date (Table 3). When individual compounds were tested using MANOVA, significant effects were observed. A- phellandrene and unknown 3 were both affected by all three parameters of site, date and phenological stage. Likewise, $\alpha$-pinene, $\beta$-pinene, cymene, sabinene, and terpinenol were all different for the effects of site and allocymene, unknown 2 and terpinene were affected by the dates of collections (Table 3 ).

There was a striking relationship between the number of compounds in the essential oil and the total quantity of extracted oil of Ledum in natural environments (Figures 4a-c). The two measures of essential oil were related strongest across sites $\left(R^{2}=0.942\right)$ and then by date $\left(R^{2}=0.457\right)$ and finally by phenological stage $\left(R^{2}=0.238\right)$. 


\section{Essential Oil and Nutrients}

The number of compounds in the essential oil correlated with the $\mathrm{C}: \mathrm{N}$ ratio across sites $\left(R^{2}=0.451\right)$, but the relationship did not hold true across collection date $\left(R^{2}=0.217\right)$ and phenological stage $\left(R^{2}=0.0665\right)$ (Figures $\left.5 \mathrm{a}-\mathrm{c}\right)$. The total quantity of essential oil was related strongest with $C: N$ across dates $\left(R^{2}=0.498\right)$, then with site $\left(R^{2}=0.319\right)$ and finally there was no relationship across phenological stage $\left(\mathrm{R}^{2}=0.119\right)$. A relationship did not exist between number of compounds and percent phosphorus across site, date or phenological stage (Figures 6a-c). However, there was a relationship between quantity of essential oil and percent phosphorus across date $\left(\mathrm{R}^{2}=0.483\right)$ but not across site $\left(\mathrm{R}^{2}=0.0112\right)$ or phenological stage $\left(\mathrm{R}^{2}=0.0002\right)$.

Independent analysis of sites revealed both the percent foliar $\mathrm{P}$ and the $\mathrm{C}: \mathrm{N}$ ratio correlated strongly with the number of compounds and the quantity of essential oil at both Livengood and Finger Mountain for the first two collections (June 13 and July 01) (Figures 7-10). Interestingly, the relationships change from negative to positive during flower production following leaf flushing in June. However, the relationship does not hold for all dates and all sites. The correlation between the total essential oil and C:N ratio was also significant for Toolik Lake on June 13, Coldfoot on Aug 16 and then at Franklin Bluffs on August 16 (Figure 7). Similarly, there was a correlation between C:N and the number of compounds for Toolik Lake on July 21 when the plants were in flower (Figure 8).

Percent phosphorus correlated with the number of compounds on August 16 at Livengood, July 21 at Finger Mountain, July 1 at Coldfoot, and June 13 and August 6 at 
Toolik Lake (Figure 9). There was no relationship between these two factors at Franklin Bluffs, the farthest north site. The quantity of essential oil was also correlated with percent phosphorus on some dates; August 16 at Finger Mountain, July 1 at Coldfoot, and June 13 and July 21 at Toolik Lake (Figure 10). Similar to the number of compounds, the quantity of essential oil and percent phosphorus was also not related at Finger Mountain on any of the collection dates.

\section{DISCUSSION}

I found that both the plant resource levels, as indicated by tissue N, P, and C, and the quality and quantity of essential oils in Ledum palustre ssp decumbens varied significantly along the latitudinal transect. A strong positive relationship was seen between the number of compounds in the essential oil and the $\mathrm{C}: \mathrm{N}$ ratio across sites. The relationship between total quantity of essential oil detectable by headspace analysis and $\mathrm{C}: \mathrm{N}$ and percent phosphorus was strongest across dates and slightly significant across sites for $\mathrm{C}: \mathrm{N}$ despite the strong correlation between the number of compounds and the quantity of terpenes in the essential oil. My intention in establishing this transect was to sample a range of plant resource levels within the natural distribution range of the species; the tissue nutrients indicate that I succeeded. However, the gradient in resources was not a simple linear change with distance (Table 2).

Finger Mountain was the most nutrient limited of the five sites with a lower concentration of both $\mathrm{N}$ and $\mathrm{P}$ with a higher $\mathrm{C}$ resulting in the largest $\mathrm{C}: \mathrm{N}$ ratio. This site is also the highest elevation site south of the Brooks Range and was similar in species composition to the other two tundra sites, despite the distance from the other tundra sites. Finger Mountain provided a comparison of a tundra site that is above treeline in terms of 
elevation, compared to other tundra sites which represent tundra beyond treeline in terms of latitude. Plants at Toolik Lake (also a tundra site) had the lowest C:N of all the collection sites including the two boreal forest locations (Livengood and Coldfoot), and was very different from the other two tundra sites (Finger Mountain and Franklin Bluffs).

The essential oil composition did vary significantly along the transect in the number of detectable components but appears to be as much a factor of elevation as latitude. Unexpectedly, all of the sites differed significantly from each other except Coldfoot and Franklin Bluffs that were nearly identical in the number of detectable components and the overall quantity of compounds detected in the headspace. These two sites differed significantly in the percent $\mathrm{P}$ but not in the $\mathrm{C}: \mathrm{N}$ ratio. Initial hypotheses for these sites were the opposite, specifically that Coldfoot would be significantly different from Franklin Bluffs in $\mathrm{C}: \mathrm{N}$ ratios, but not necessarily in the $\% \mathrm{P}$, and that these differences would affect the essential oil production.

Lerdau and coauthors (1995) suggest that optimal study periods to test the relationship between resource allocation and defensive compound production are during periods of growth or reproductive efforts. Due to the nature of the arctic climate, the sampling scheme presented here allowed for a study of the full range of phenological expression in Ledum and therefore a means of testing predictions based on plant resource availability and allocation to defensive compounds (Loomis 1932, Bryant et. al. 1985, Lorio 1986, Bryant 1987, and Hermes 1992). Toolik Lake had the largest seasonal effect on the number of components present with a reduction from 17 components on June 13 to 4 on August 6. At Toolik Lake, leaves of Ledum increased for $\mathrm{N}$ as the season progressed from June 13 to August 16 correlating with the decrease in the number of components. 
Despite the Toolik Lake findings, there does not appear to be a clear trend in the number of detectable components and the amount of the nutrients over the course of the season. Seasonally, July 21 had the lowest percent of all the nutrients and was significantly lower for all three nutrients yet was in the middle for the number of components. When nutrients were examined with phenological stage, nitrogen and phosphorus were lowest at the ripening of seed capsules. Allocymene was also significantly higher during this phenological stage than all others, suggesting allocymene is related to the ripening of seed capsules or when nitrogen and phosphorus are at a lower percentage in the leaves. It is possible that the decrease in leaf nitrogen and phosphorus is related to the ripening of seed capsules and the production of allocymene is related to the production of seeds more than to changes in nutrients.

Analysis of the individual compounds revealed significant differences with site and time of year. Alpha phellandrene was present in significantly higher quantities in plants at Toolik Lake than all other sites, suggesting the quantity is related to the amount of nitrogen available. This pattern also held true for Finger Mountain, which had the highest $\mathrm{C}: \mathrm{N}$ ratio and the lowest quantity of $\alpha$ phellandrene. The correlation between essential oil quantity and the $\mathrm{C}: \mathrm{N}$ ratio and foliar percent $\mathrm{P}$ when the plants are in flower suggests that there is a relationship between phenological stage and essential oil production in this species. This has also been seen in other model systems suggesting Ledum follows predictions formulated through the study of other species (Powell and Adams 1973, Coley et. al. 1985 and Belleau and Collin 1993). That this relationship is not seen uniformly in Ledum suggests that other factors are mitigating this relationship. Both Livengood and Finger Mountain had a strong correlation between the percent 
phosphorus and the number of compounds on 3 of the 4 dates sampled. While not assessed directly in this study, the timing of production of specific compounds with phenological stage might affect the interaction of Ledum with pollinators, herbivores and in allelopathic interactions (Belleau and Collin 1983, Bryant 1985, Sveinbjornsson 1992, Inderjit and Mallik 1997, and Suzuki and Kudo 1997). This variation coupled with changes in nutrient availability as predicted by climate change models suggests broader impacts with variation in the essential oil components.

Previous studies have failed to document any relationship between changes in the overall number of compounds in the essential oil and the overall quantity of the essential oil. The strong positive relationship between the number of compounds and the quantity of essential oil across sites suggests that there is not a trade-off between the number of compounds and the total quantity of essential oil. The positive relationship between the number of compounds and the $\mathrm{C}: \mathrm{N}$ ratio across sites suggests that quantity and diversity of the essential oil increases as the rate of carbon assimilation relative to the amount of nitrogen sequestered within the leaf increases. Previous works have established similar relationships between secondary compound production and nutrient availability (Zangerl 1986, Ruohomaki et. al. 1996, and Hamilton et. al. 2000).

The expression of specific compounds in the essential oil of L. palustre ssp decumbens is also likely affected by resource availability. That the specific compounds differ and that the major component varies based on nutrient availability and environmental and community factors suggests that changes in these factors will affect the essential oil of this plant. Terpenoid compounds found in essential oils are important components in plant - herbivore interactions and allelopathy. Environmentally mediated 
variation in these compounds might influence changes at several levels of community interactions. The variation in timing of specific compounds in different communities might also be an important key in understanding the effects of climate change on sensitive communities such as the Arctic. Further work is required to tease apart those factors that might be responsible for the patterns in essential oils found along the transect, such as light, nutrients, and temperature. 
Table 1. Study sites along the latitudinal transect in Alaska. Sites are from south to north.

\begin{tabular}{|c|c|c|c|c|}
\hline \multirow[b]{2}{*}{ SITE } & \multicolumn{4}{|c|}{ Site Description } \\
\hline & $\begin{array}{c}\text { Vegetation } \\
\text { Type }\end{array}$ & $\begin{array}{l}\text { Latitude and } \\
\text { Longitude }\end{array}$ & $\begin{array}{l}\text { Elevation } \\
\text { (m) }\end{array}$ & Site Description \\
\hline Livengood & Boreal forest & $65^{\circ} 34^{\prime} \mathrm{N}, 148^{\circ} 5^{\prime} \mathrm{W}$ & 231 & $120 \mathrm{~km}$ north of Fairbanks, AK \\
\hline $\begin{array}{l}\text { Finger } \\
\text { Mountain }\end{array}$ & Tundra & $66^{\circ} 20^{\prime} \mathrm{N}, 150^{\circ} 26^{\prime} \mathrm{W}$ & 565 & $\begin{array}{c}\text { Finger Mountain, Above treeline } \\
\text { south of the Brooks Range }\end{array}$ \\
\hline Coldfoot & $\begin{array}{l}\text { Boreal } \\
\text { Forest }\end{array}$ & $67^{\circ} 16^{\prime} \mathrm{N}, 150^{\circ} 10^{\prime} \mathrm{W}$ & 335 & $\begin{array}{c}\text { Coldfoot, AK, Southern foothills } \\
\text { of Brooks Range }\end{array}$ \\
\hline $\begin{array}{l}\text { Toolik } \\
\text { Lake }\end{array}$ & Tundra & $68^{\circ} 38^{`} \mathrm{~N}, 149^{\circ} 34^{\prime} \mathrm{W}$ & 760 & $\begin{array}{l}\text { Toolik Lake, AK Northern } \\
\text { foothills of Brooks Range }\end{array}$ \\
\hline $\begin{array}{l}\text { Franklin } \\
\text { Bluffs }\end{array}$ & Tundra & $69^{\circ} 18^{\prime} \mathrm{N}, 148^{\circ} 45^{\prime} \mathrm{W}$ & 281 & $\begin{array}{c}120 \mathrm{~km} \text { north of Toolik Lake. } \\
\text { AK }\end{array}$ \\
\hline
\end{tabular}


Table 2. Leaf nutrients of Ledum palustre ssp decumbens along the latitudinal gradient by Site (from S to N, Livengood, Finger Mountain, Coldfoot, Toolik Lake, and Franklin Bluffs), Date (June 13, July 01, July 21, and Aug 16) and by Phenological Stage (as progressed through season; Snow free, in Bud, in Flower, Flower Senescing, Flower Dropped, Capsules Expanding). Values are mean \pm SE. Within a column, means with the same superscript are not significantly different at $p>0.05$ using comparison of means within a two-way ANOVA. $\mathrm{N}=20$ per site and date. All measurements were arcsine squareroot transformed for analysis.

\begin{tabular}{lcc}
\hline & \multicolumn{2}{c}{ NUTRIENT } \\
\cline { 2 - 3 } & \multicolumn{1}{c}{$\mathrm{C}: \mathrm{N}$} & $\mathrm{P}$ \\
\hline SITE & & \\
Livengood & $39.09 \pm 1.12^{\mathrm{b}}$ & $0.1391 \pm 0.001^{\mathrm{bc}}$ \\
Finger Mountain & $42.52 \pm 0.98^{\mathrm{c}}$ & $0.1083 \pm 0.001^{\mathrm{a}}$ \\
Coldfoot & $39.61 \pm 1.01^{\mathrm{b}}$ & $0.1190 \pm 0.001^{\mathrm{ab}}$ \\
Toolik Lake & $32.88 \pm 0.98^{\mathrm{a}}$ & $0.1530 \pm 0.001^{\mathrm{c}}$ \\
Franklin Bluffs & $40.93 \pm 1.01^{\mathrm{bc}}$ & $0.1582 \pm 0.001^{\mathrm{c}}$ \\
\hline DATE & & \\
June 13 & $37.00 \pm 0.92^{\mathrm{a}}$ & $0.1416 \pm 0.007^{\mathrm{b}}$ \\
July 01 & $37.82 \pm 0.94^{\mathrm{a}}$ & $0.1329 \pm 0.007^{\mathrm{ab}}$ \\
July 21 & $41.67 \pm 0.90^{\mathrm{b}}$ & $0.1128 \pm 0.005^{\mathrm{a}}$ \\
Aug 16 & $39.53 \pm 0.90^{\mathrm{ab}}$ & $0.1479 \pm 0.024^{\mathrm{b}}$ \\
\hline PHENOLOGICAL STAGE & \\
Snow free & $37.31 \pm 0.86^{\mathrm{a}}$ & $0.1275 \pm 0.006^{\mathrm{ab}}$ \\
Bud & $36.35 \pm 2.20^{\mathrm{ab}}$ & $0.1308 \pm 0.015^{\mathrm{abc}}$ \\
Flower & $35.02 \pm 1.13^{\mathrm{a}}$ & $0.1607 \pm 0.007^{\mathrm{c}}$ \\
Flower senescing & $44.37 \pm 1.39^{\mathrm{c}}$ & $0.1038 \pm 0.007^{\mathrm{a}}$ \\
Flower dropped & $40.26 \pm 1.01^{\mathrm{b}}$ & $0.1225 \pm 0.005^{\mathrm{ab}}$ \\
Capsules expanding & $41.26 \pm 1.01^{\mathrm{b}}$ & $0.1488 \pm 0.031^{\mathrm{bc}}$ \\
\hline
\end{tabular}


Table 3. Results of two-way ANOVA for Site and Date and for Site and Phenological stage on measured parameters in this study $(\% \mathrm{~N}, \mathrm{P}$, and $\mathrm{C}$, total quantity essential oil, number of essential oil compounds, and individual components). Significance is shown at $\mathrm{P}<.05, .01$, and $.001 \mathrm{by}^{*},{ }^{* *}$, and $* * *$ respectively. Lack of statistical significance is shown as NS.

\begin{tabular}{lccccc}
\hline \multicolumn{1}{c}{ Parameter } & Site & Date & Site*Date & Pheno & Site* Pheno \\
\hline $\mathrm{P}$ & $* *$ & $\mathrm{NS}$ & $\mathrm{NS}$ & $* *$ & $* *$ \\
$\mathrm{C}: \mathrm{N}$ & $* * *$ & $* *$ & $* * *$ & $* * *$ & $* * *$ \\
Essential Oil Quantity & $* * *$ & $\mathrm{NS}$ & $\mathrm{NS}$ & $\mathrm{NS}$ & $\mathrm{NS}$ \\
Number of Components & $* * *$ & $* * *$ & $* * *$ & $* * *$ & $* * *$ \\
$\alpha$ - pinene & $*$ & $\mathrm{NS}$ & $*$ & $\mathrm{NS}$ & $*$ \\
Camphene & $\mathrm{NS}$ & $\mathrm{NS}$ & $\mathrm{NS}$ & $\mathrm{NS}$ & $\mathrm{NS}$ \\
Unknown 1 & $\mathrm{NS}$ & $\mathrm{NS}$ & $\mathrm{NS}$ & $\mathrm{NS}$ & $\mathrm{NS}$ \\
$\beta$-pinene & $*$ & $\mathrm{NS}$ & $*$ & $\mathrm{NS}$ & $\mathrm{NS}$ \\
$\alpha$-phellandrene & $* *$ & $* * *$ & $* * *$ & $* *$ & $* * *$ \\
Allocymene & $\mathrm{NS}$ & $* * *$ & $\mathrm{NS}$ & $* *$ & $\mathrm{NS}$ \\
Cymene & $*$ & $\mathrm{NS}$ & $\mathrm{NS}$ & $\mathrm{NS}$ & $*$ \\
Unknown 2 & $\mathrm{NS}$ & $*$ & $\mathrm{NS}$ & $\mathrm{NS}$ & $\mathrm{NS}$ \\
Sabinene & $*$ & $\mathrm{NS}$ & $\mathrm{NS}$ & $\mathrm{NS}$ & $\mathrm{NS}$ \\
Unknown3 & $* * *$ & $* * *$ & $* * *$ & $* * *$ & $* * *$ \\
Terpinenol & $* * *$ & $\mathrm{NS}$ & $\mathrm{NS}$ & $\mathrm{NS}$ & $\mathrm{NS}$ \\
Terpinene & $\mathrm{NS}$ & $* * *$ & $* *$ & $* *$ & $\mathrm{NS}$ \\
& & & & & \\
\hline
\end{tabular}


Table 4. Percent of essential oil in headspace of Ledum palustre ssp decumbens along latitudinal gradient by Site (1, 2, 3, 4, and 5 ). Values are mean \pm SE. Within a row, means with the same superscript are not significant at $p>0.05$ using comparison of means within a two-way ANOVA. All measurements were arcsine squareroot transformed. Rt is the compound retention time.

\begin{tabular}{ccccccc}
\hline & & \multicolumn{5}{c}{ SITE } \\
\cline { 2 - 6 } Rt & COMPOUND & Livengood & Finger Mountain & Coldfoot & Toolik Lake & Franklin Bluffs \\
\hline Number of Compounds & $26 \pm 1^{\mathrm{d}}$ & $17 \pm 1^{\mathrm{b}}$ & $20 \pm 1^{\mathrm{c}}$ & $11 \pm 1^{\mathrm{a}}$ & $21 \pm 1^{\mathrm{c}}$ \\
Quantity of Essential Oil & $2.29 \mathrm{E} 9 \pm 3.51 \mathrm{E} 8^{\mathrm{c}}$ & $1.07 \mathrm{E} 9 \pm 3.09 \mathrm{E} 8^{\mathrm{a}}$ & $1.23 \mathrm{E} 9 \pm 3.188^{\mathrm{ab}}$ & $3.92 \mathrm{E} 8 \pm 3.18 \mathrm{E} 8^{\mathrm{a}}$ & $1.98 \mathrm{E} 9 \pm 3.18 \mathrm{E} 8^{\mathrm{bc}}$ \\
4.0 & $\alpha$ - pinene & $6.75 \pm 7.3^{\mathrm{a}}$ & $5.99 \pm 3.0^{\mathrm{a}}$ & $5.57 \pm 0.811^{\mathrm{a}}$ & $4.95 \pm 0.8^{\mathrm{a}}$ & $7.19 \pm 0.6^{\mathrm{a}}$ \\
4.2 & camphene & $1.33 \pm 0.3^{\mathrm{a}}$ & $0.813 \pm 0.2^{\mathrm{a}}$ & $2.87 \pm 2.0^{\mathrm{a}}$ & $1.74 \pm 0.8^{\mathrm{a}}$ & $4.26 \pm 2.0^{\mathrm{a}}$ \\
4.6 & unknown 1 & $0.31 \pm 0.2^{\mathrm{b}}$ & $0.99 \pm 0.4^{\mathrm{b}}$ & $0.253 \pm 0.3^{\mathrm{a}}$ & $0.186 \pm 0.1^{\mathrm{b}}$ & $1.12 \pm 0.4^{\mathrm{b}}$ \\
4.7 & $\beta$ - pinene & $9.81 \pm 2.0^{\mathrm{a}}$ & $6.55 \pm 0.4^{\mathrm{a}}$ & $6.38 \pm 0.7^{\mathrm{a}}$ & $7.07 \pm 1.1^{\mathrm{a}}$ & $9.47 \pm 1.7^{\mathrm{a}}$ \\
5.2 & $\alpha$-phellandrene & $0.09 \pm 0.04^{\mathrm{a}}$ & $0.07 \pm 0.03^{\mathrm{a}}$ & $0.17 \pm 0.07^{\mathrm{a}}$ & $0.51 \pm 0.2^{\mathrm{b}}$ & $0.12 \pm 0.06^{\mathrm{a}}$ \\
5.4 & allocymene & $1.81 \pm 0.9^{\mathrm{a}}$ & $4.15 \pm 1.25^{\mathrm{b}}$ & $4.09 \pm 1.7^{\mathrm{a}}$ & $2.36 \pm 0.8^{\mathrm{a}}$ & $2.69 \pm 0.8^{\mathrm{a}}$ \\
5.6 & cymene & $47.2 \pm 3.2^{\mathrm{a}}$ & $52.7 \pm 3.6^{\mathrm{a}}$ & $52.6 \pm 3.4^{\mathrm{a}}$ & $62.5 \pm 4.7^{\mathrm{b}}$ & $49.8 \pm 3.6^{\mathrm{a}}$ \\
5.7 & unknown 2 & $2.18 \pm 0.6^{\mathrm{a}}$ & $5.49 \pm 2.9^{\mathrm{a}}$ & $0.79 \pm 0.5^{\mathrm{a}}$ & $1.11 \pm 0.6^{\mathrm{a}}$ & $3.59 \pm 1.3^{\mathrm{a}}$ \\
6.3 & sabinene & $2.03 \pm 0.2^{\mathrm{ab}}$ & $2.88 \pm 0.3^{\mathrm{ab}}$ & $2.07 \pm 0.4^{\mathrm{a}}$ & $1.93 \pm 0.4^{\mathrm{a}}$ & $3.39 \pm 0.7^{\mathrm{b}}$ \\
9.3 & unknown 3 & $1.66 \pm 0.8^{\mathrm{b}}$ & $0.05 \pm 0.05^{\mathrm{a}}$ & $0.15 \pm 0.1^{\mathrm{a}}$ & $0 \pm 0^{\mathrm{a}}$ & $0.05 \pm 0.04^{\mathrm{a}}$ \\
10.1 & terpinen-4-ol & $12.3 \pm 1.8^{\mathrm{c}}$ & $6.44 \pm 1.5^{\mathrm{ab}}$ & $10.2 \pm 2.1^{\mathrm{b}}$ & $3.43 \pm 1.0^{\mathrm{a}}$ & $6.21 \pm 1.1^{\mathrm{a}}$ \\
11.7 & terpinene & $0.145 \pm 0.01^{\mathrm{b}}$ & $0.139 \pm 0.01^{\mathrm{a}}$ & $0.148 \pm 0.02^{\mathrm{a}}$ & $0.142 \pm 0.03^{\mathrm{a}}$ & $0.121 \pm 0.01^{\mathrm{a}}$ \\
& $\mathrm{n}$ & 17 & 20 & 19 & 20 & 19 \\
\hline
\end{tabular}


Table 5. Percent of each compound in the headspace of Ledum palustre ssp decumbens along latitudinal gradient by Date (June 13, July 01 . July 21, and August 16). Values are mean \pm SE. Within a row, means with the same superscript are not significantly at $p>$ 0.05 using comparison of means within a two-way ANOVA. All measurements were arcsine squareroot transformed for analysis. $\mathrm{Rt}$ is the compound retention time.

\begin{tabular}{cccccc}
\hline & & \multicolumn{3}{c}{ DATE } \\
\cline { 2 - 6 } Rt & COMPOUND & June 13 & July 01 & July 21 & August 16 \\
\hline \multicolumn{2}{c}{ Number of Compounds } & $22 \pm 1^{\mathrm{c}}$ & $22 \pm 1^{\mathrm{c}}$ & $19 \pm 1^{\mathrm{b}}$ & $12 \pm 1^{\mathrm{a}}$ \\
Quantity of Essential Oil & $1.34 \mathrm{E} 9 \pm 2.89 \mathrm{E} 8^{\mathrm{a}}$ & $1.78 \mathrm{E} 9 \pm 3.00 \mathrm{E} 8^{\mathrm{a}}$ & $1.20 \mathrm{E} 9 \pm 2.83 \mathrm{E} 8^{\mathrm{a}}$ & $1.24 \mathrm{E} 9 \pm 2.83 \mathrm{E} 8^{\mathrm{a}}$ \\
4.00 & $\alpha$ - pinene & $6.12 \pm 0.6^{\mathrm{a}}$ & $6.05 \pm 0.5^{\mathrm{a}}$ & $6.43 \pm 0.6^{\mathrm{a}}$ & $5.63 \pm 0.7^{\mathrm{a}}$ \\
4.23 & camphene & $2.35 \pm 01.1^{\mathrm{a}}$ & $1.24 \pm 0.2^{\mathrm{a}}$ & $2.40 \pm 1.1^{\mathrm{a}}$ & $2.76 \pm 1.5^{\mathrm{a}}$ \\
4.60 & unknown 1 & $0.19 \pm 0.2^{\mathrm{a}}$ & $0.77 \pm 0.23^{\mathrm{b}}$ & $0.73 \pm 0.3^{\mathrm{a}}$ & $0.60 \pm 0.33^{\mathrm{a}}$ \\
4.70 & $\beta$ - pinene & $6.15 \pm 0.65^{\mathrm{a}}$ & $8.69 \pm 1.5^{\mathrm{a}}$ & $8.96 \pm 1.3^{\mathrm{a}}$ & $7.29 \pm 0.84^{\mathrm{a}}$ \\
5.18 & a-phellandrene & $0.55 \pm 0.16^{\mathrm{c}}$ & $0.20 \pm 0.06^{\mathrm{b}}$ & $0.04 \pm 0.03^{\mathrm{a}}$ & $0 \pm 0^{\mathrm{a}}$ \\
5.40 & allocymene & $3.04 \pm 1.1^{\mathrm{a}}$ & $6.20 \pm 1.4^{\mathrm{b}}$ & $2.69 \pm 0.7^{\mathrm{a}}$ & $0.42 \pm 0.17^{\mathrm{a}}$ \\
5.60 & cymene & $49.0 \pm 2.9^{\mathrm{a}}$ & $50.1 \pm 3.1^{\mathrm{a}}$ & $54.5 \pm 2.77^{\mathrm{a}}$ & $58.7 \pm 4.74^{\mathrm{a}}$ \\
5.70 & unknown & $1.87 \pm 0.95^{\mathrm{a}}$ & $4.75 \pm 1.4^{\mathrm{b}}$ & $1.34 \pm 0.6^{\mathrm{a}}$ & $2.78 \pm 2.2^{\mathrm{ab}}$ \\
6.30 & sabinene & $2.31 \pm 0.3^{\mathrm{a}}$ & $2.63 \pm 0.3^{\mathrm{a}}$ & $2.85 \pm 0.6^{\mathrm{a}}$ & $2.08 \pm 0.3^{\mathrm{a}}$ \\
9.30 & unknown 3 & $0.63 \pm 0.4^{\mathrm{b}}$ & $0.78 \pm 0.4^{\mathrm{b}}$ & $0 \pm 0^{\mathrm{a}}$ & $0.01 \pm 0.01^{\mathrm{a}}$ \\
10.1 & terpinen-4-ol & $8.68 \pm 2.0^{\mathrm{b}}$ & $5.82 \pm 1.43^{\mathrm{a}}$ & $7.19 \pm 1.0^{\mathrm{a}}$ & $8.56 \pm 1.4^{\mathrm{b}}$ \\
11.7 & terpinene & $19.1 \pm 1.8^{\mathrm{b}}$ & $12.7 \pm 1.45^{\mathrm{a}}$ & $12.8 \pm 0.95^{\mathrm{a}}$ & $11.2 \pm 1.2^{\mathrm{a}}$ \\
\hline
\end{tabular}


Table 6. Percent of each compound in the headspace of Ledum palustre ssp decumbens along latitudinal gradient by phenological stage (Snowfree, Bud, Flower, Flowers Dropped, Capsules Ripening, Capsules Dehisced). Values are mean \pm SE. Within a row, means with the same superscript are not significantly at $\mathrm{p}>0.05$ using comparison of means within a two-way ANOVA. All measurements were arcsine squareroot transformed. $\mathrm{Rt}$ is the compound retention time.

\begin{tabular}{|c|c|c|c|c|c|c|c|}
\hline \multirow[b]{2}{*}{$\mathrm{Rt}$} & \multirow[b]{2}{*}{ Compound } & \multicolumn{6}{|c|}{ PHENOLOGICAL STAGE } \\
\hline & & Snowfree & Bud & Flower & $\begin{array}{l}\text { Flowers } \\
\text { Dropped }\end{array}$ & $\begin{array}{l}\text { Capsules } \\
\text { Ripening }\end{array}$ & $\begin{array}{l}\text { Capsules } \\
\text { Dehisced }\end{array}$ \\
\hline \multicolumn{2}{|c|}{ Number of compound } & $16 \pm 1^{\mathrm{a}}$ & $18 \pm 1^{\text {ab }}$ & $\overline{25 \pm 2}$ & $17 \pm 2^{a}$ & $17 \pm 1^{a}$ & $14 \pm 1^{a}$ \\
\hline \multicolumn{2}{|c|}{ Quantity of Oil } & $5.92 \mathrm{E} 8 \pm 3.71 \mathrm{E} 8^{\mathrm{a}}$ & $5.91 \mathrm{E} 8 \pm 6.90 \mathrm{E} 8^{\mathrm{a}}$ & $2.15 \mathrm{E} 9 \pm 2.71 \mathrm{E} 8^{\mathrm{b}}$ & $1.23 \mathrm{E} 9 \pm 3.18 \mathrm{E}^{\mathrm{a}}$ & $1.03 \mathrm{E} 9 \pm 4.36 \mathrm{E} 8^{\mathrm{a}}$ & $1.40 \mathrm{E} 9 \pm 3.18 \mathrm{E} 8^{b}$ \\
\hline 4.0 & $\alpha$ - pinene & $6.59 \pm 0.5^{\mathrm{a}}$ & $3.91 \pm 0.8^{\mathrm{a}}$ & $6.23 \pm 0.7^{\mathrm{a}}$ & $5.17 \pm 0.7^{\mathrm{a}}$ & $6.27 \pm 0.5^{\mathrm{a}}$ & $6.67 \pm 0.7^{\mathrm{a}}$ \\
\hline 4.2 & camphene & $3.17 \pm 1.7^{\mathrm{a}}$ & $0 \pm 0^{\mathrm{a}}$ & $18.5 \pm 0.6$ & $1.95 \pm 1.2^{\mathrm{a}}$ & $0.86 \pm 0.3^{\mathrm{a}}$ & $3.35 \pm 1.9^{\mathrm{a}}$ \\
\hline 4.6 & unknown 1 & $0.42 \pm 0.3^{\mathrm{ab}}$ & $0 \pm 0^{\mathrm{a}}$ & $0.29 \pm 0.14$ & $0.53 \pm 0.3^{\mathrm{ab}}$ & $1.58 \pm 0.6^{\mathrm{b}}$ & $0.75 \pm 0.41^{\mathrm{ab}}$ \\
\hline 4.7 & $\beta$-pinene & $7.71 \pm 0.7^{\mathrm{a}}$ & $3.7 \pm 0.8^{\mathrm{a}}$ & $8.26 \pm 1.4$ & $8.32 \pm 1.7^{\mathrm{a}}$ & $7.12 \pm 0.56^{\mathrm{a}}$ & $7.85 \pm 0.7^{\mathrm{a}}$ \\
\hline 5.2 & $\alpha$-phellandrene & $0.68 \pm 0.2^{b}$ & $3.5 \pm 0.26^{b}$ & $0.20 \pm 0.10$ & $0.1 \pm 0.14^{\mathrm{a}}$ & $0.1 \pm 0.1^{a}$ & $O \pm O^{a}$ \\
\hline 5.4 & allocymene & $3.17 \pm 1.1^{\mathrm{a}}$ & $2.6 \pm 2.6^{\mathrm{a}}$ & $4.40 \pm 1.4$ & $2.6 \pm 0.8^{a}$ & $5.66 \pm 1.5^{b}$ & $0.28 \pm 0.1^{a}$ \\
\hline 5.6 & cymene & $49.8 \pm 3.2^{\mathrm{a}}$ & $52.9 \pm 7.1^{\mathrm{a}}$ & $51.9 \pm 3.5$ & $57.8 \pm 4.6^{\mathrm{a}}$ & $53.1 \pm 3.2^{a}$ & $52.8 \pm 4.4^{a}$ \\
\hline 5.7 & unknown 2 & $3.33 \pm 1.5^{\mathrm{a}}$ & $0 \pm 0^{\mathrm{a}}$ & $2.31 \pm 0.60$ & $1.24 \pm 0.6^{\mathrm{a}}$ & $4.86 \pm 3.2^{\mathrm{a}}$ & $3.51 \pm 3.0^{\mathrm{a}}$ \\
\hline 6.3 & sabinene & $2.32 \pm 0.33^{\mathrm{a}}$ & $1.53 \pm 0.7^{\mathrm{a}}$ & $2.31 \pm 0.30$ & $2.85 \pm 0.7^{\mathrm{a}}$ & $3.37 \pm 0.4^{\mathrm{a}}$ & $2.14 \pm 0.3^{\mathrm{a}}$ \\
\hline 9.3 & unknown 3 & $0.01 \pm 0.01^{\mathrm{a}}$ & $0.3 \pm 0.3^{\mathrm{ab}}$ & $1.15 \pm 0.50$ & $0 \pm 0^{\mathrm{a}}$ & $0 \pm 0^{\mathrm{a}}$ & $0.01 \pm 0.01^{\mathrm{a}}$ \\
\hline 10.1 & terpinen-4-ol & $3.86 \pm 1.1^{\mathrm{a}}$ & $12.8 \pm 7.3^{b}$ & $8.38 \pm 1.70$ & $7.70 \pm 1.2^{\mathrm{ab}}$ & $4.32 \pm 1.3^{\mathrm{a}}$ & $9.79 \pm 1.6^{\mathrm{b}}$ \\
\hline \multirow[t]{2}{*}{11.7} & terpinene & $18.9 \pm 2.8^{\mathrm{b}}$ & $2.18 \pm 3.5^{\mathrm{b}}$ & $12.7 \pm 1.30$ & $11.8 \pm 1.3^{\mathrm{a}}$ & $12.7 \pm 0.01^{\mathrm{ab}}$ & $12.8 \pm 0.9^{\mathrm{ab}}$ \\
\hline & $\mathrm{n}$ & 15 & 4 & 27 & 20 & 10 & 20 \\
\hline
\end{tabular}


Figure 1. Map of Alaska showing locations of transect sites (Livengood, Finger Mt, Coldfoot, Toolik Lake, and Franklin Bluffs) as black dots. (Map provided courtesy of Institute of Arctic Biology, University of Alaska Fairbanks).

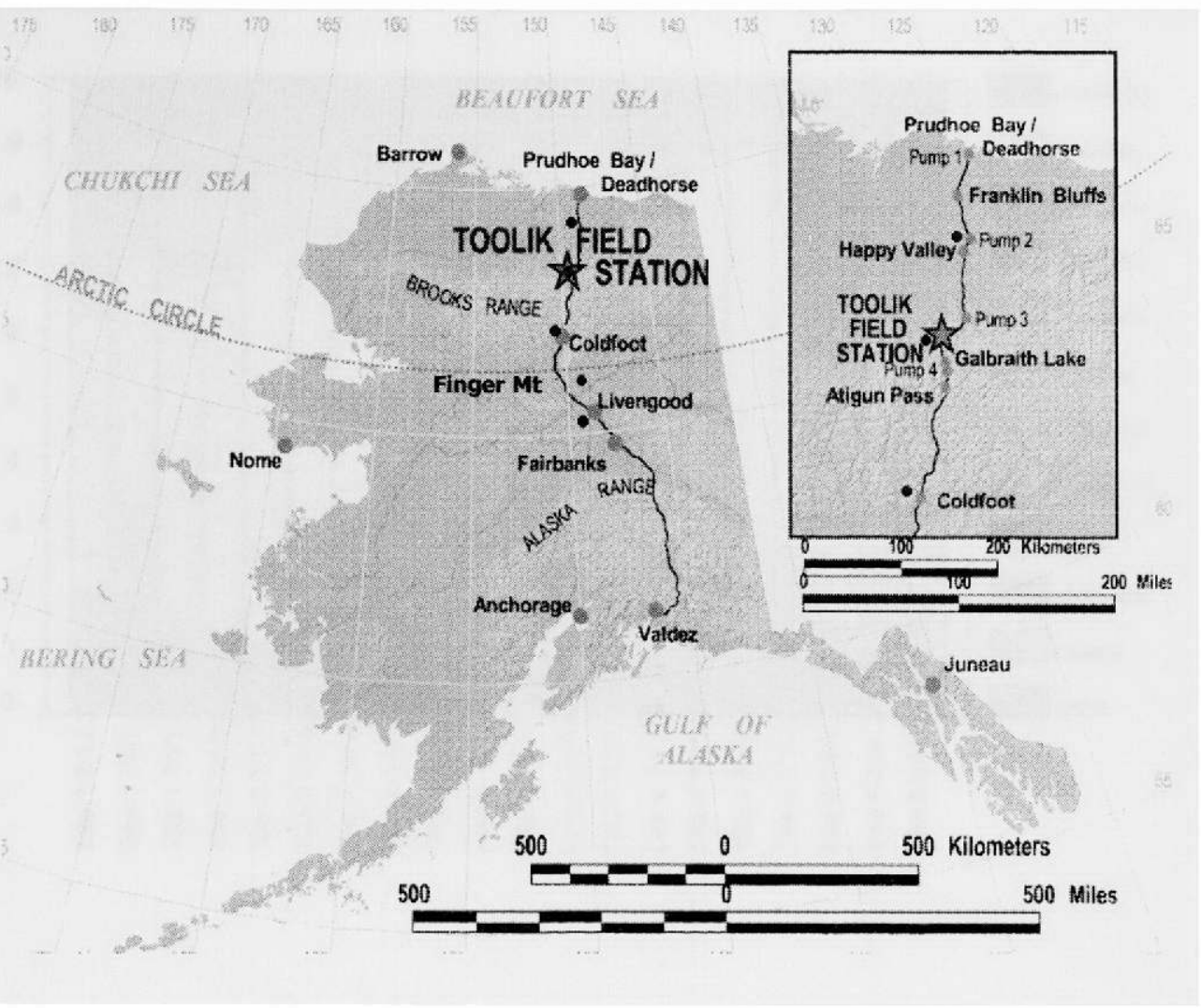

Figure 2: Diurnal variation in the essential oil of Ledum palustre ssp decumbens collected on Aug 21, 2002 at Toolik Lake. Collection times relevant to transect collections are within the boxed area. Values are means of six samples.

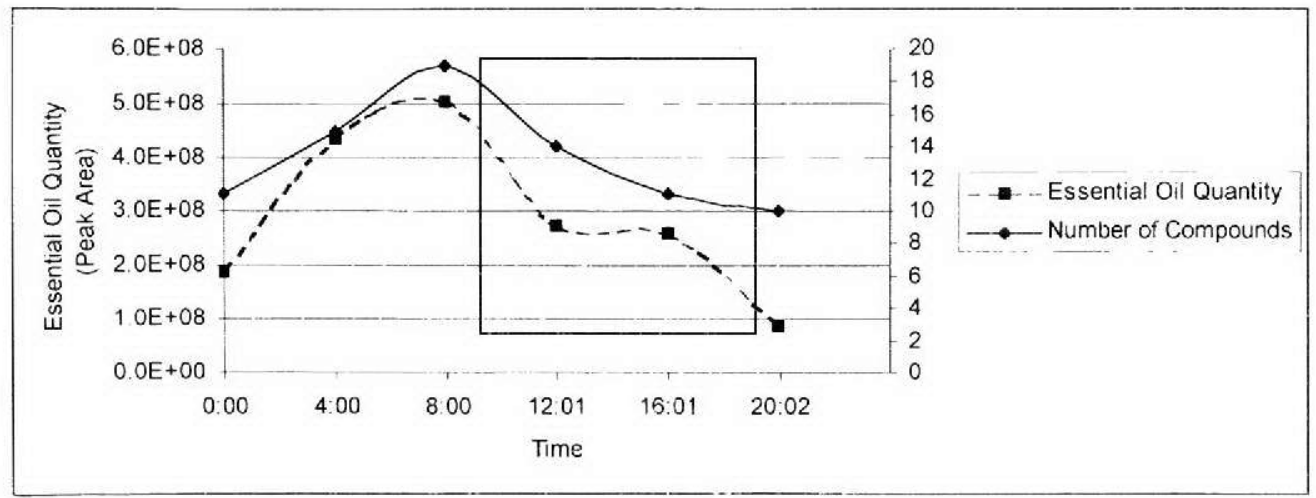


Figure 3: Proportional allocation of each compound in the headspace of Ledum palustre ssp decumbens at each collection site (Livengood (1), Finger Mountain (2), Coldfoot (3), Toolik Lake (4), and Franklin Bluffs (5)) and date (June 13, July 01, July 21, and August 16) along a latitudinal transect. Data are represented as mean values.

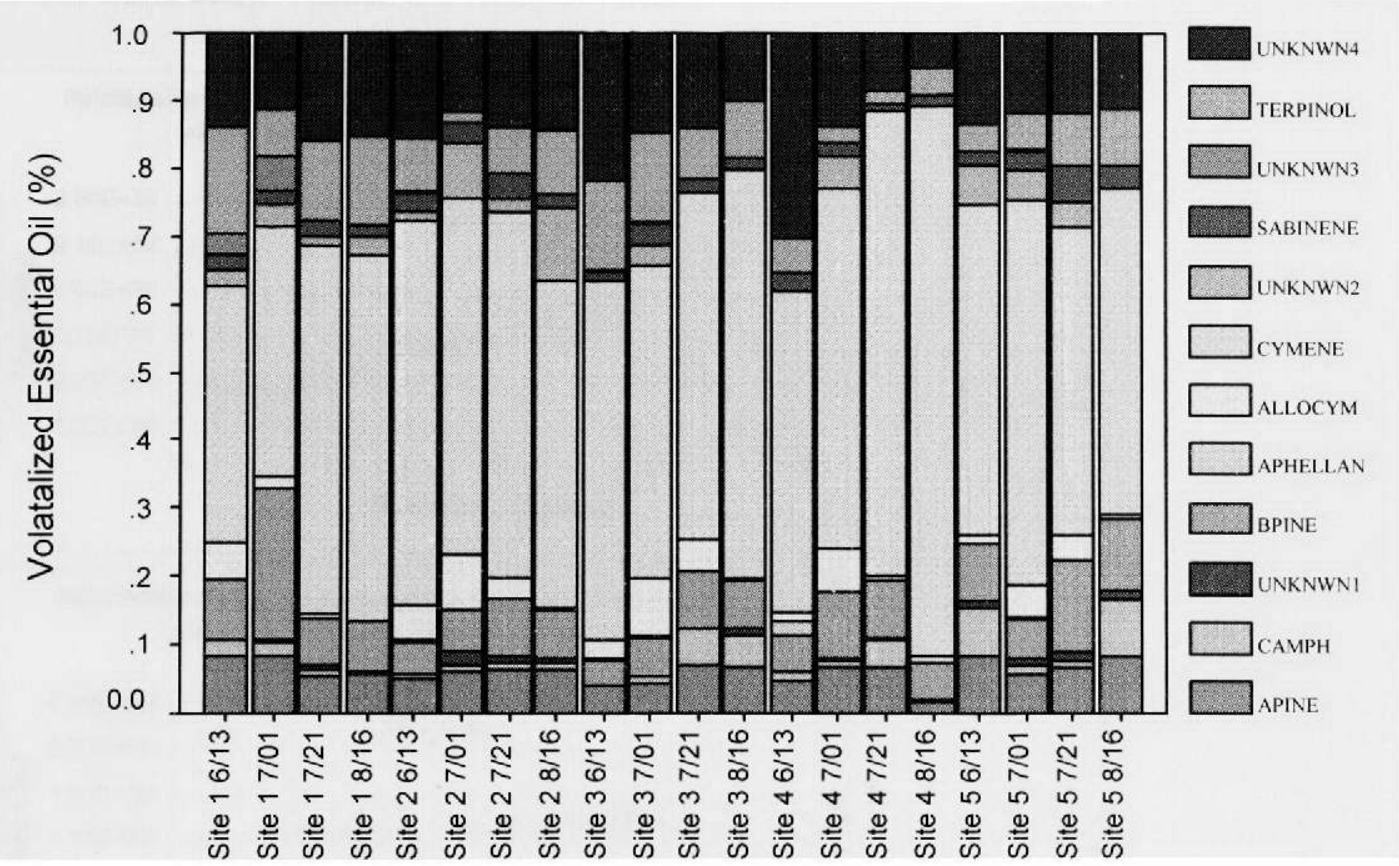


Figure 4. Relationship between the quantity of essential oil and the number of compounds in the essential oil in Ledum palustre ssp decumbens by a: site (Livengood, Finger Mt, Coldfoot, Toolik Lake, and Franklin Bluffs), b: date (June 13, July 01, July 21, Aug 16), and c: phenological stage (Snowfree, bud, flower, flower senescing, capsules expanding, capsules dehisced). Values are means \pm S.E.
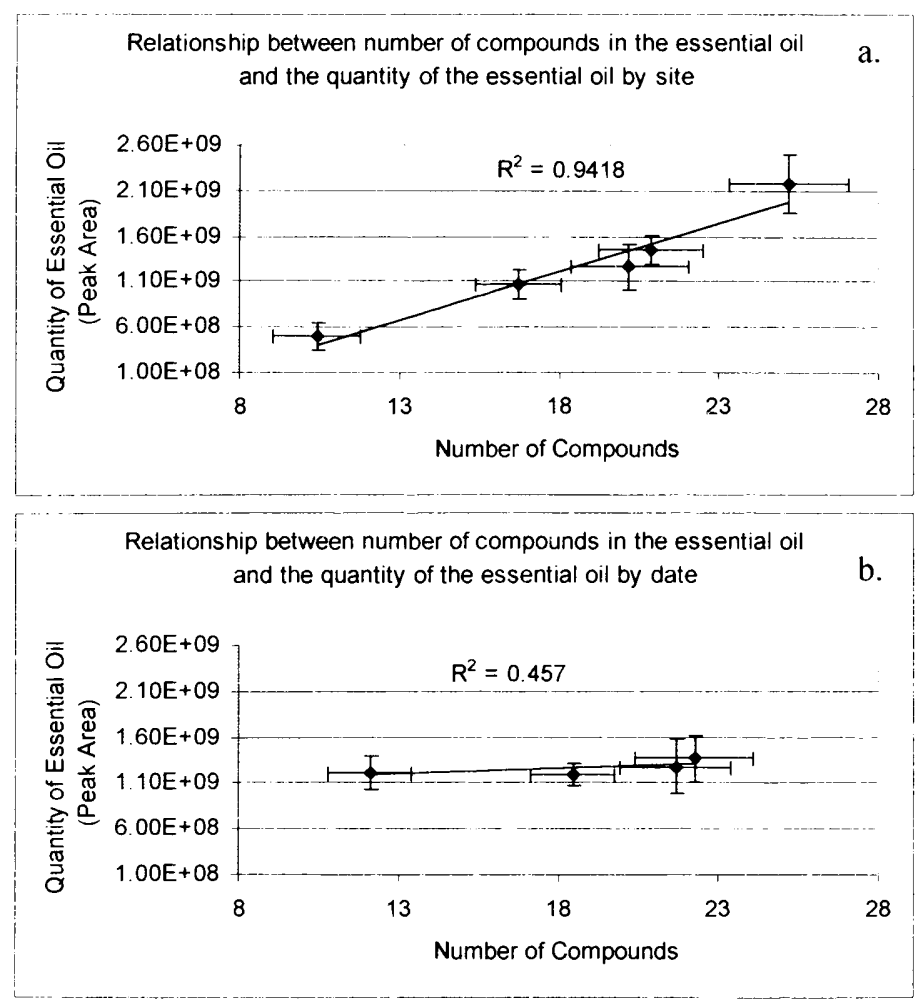

Relationship between number of compounds in the essential oil and the quantity of the essential oil by phenological stage

c.

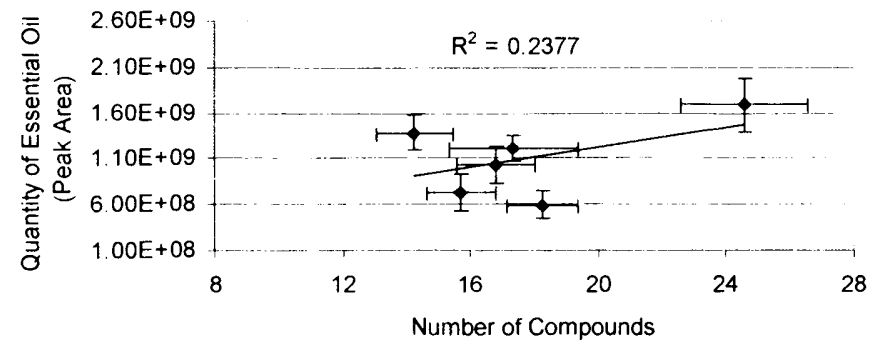


Figure 5. Relationship between foliar $\mathrm{C}: \mathrm{N}$ and the quantity and number of compounds in the essential oil of Ledum palustre ssp decumbens by a: site (Livengood, Finger Mt, Coldfoot, Toolik Lake, and Franklin Bluffs), b: date (June 13, July 01, July 21, Aug 16). and c: phenological stage (Snowfree, bud, flower, flowers senescing, capsules expanding, capsules dehisced). Values are means.
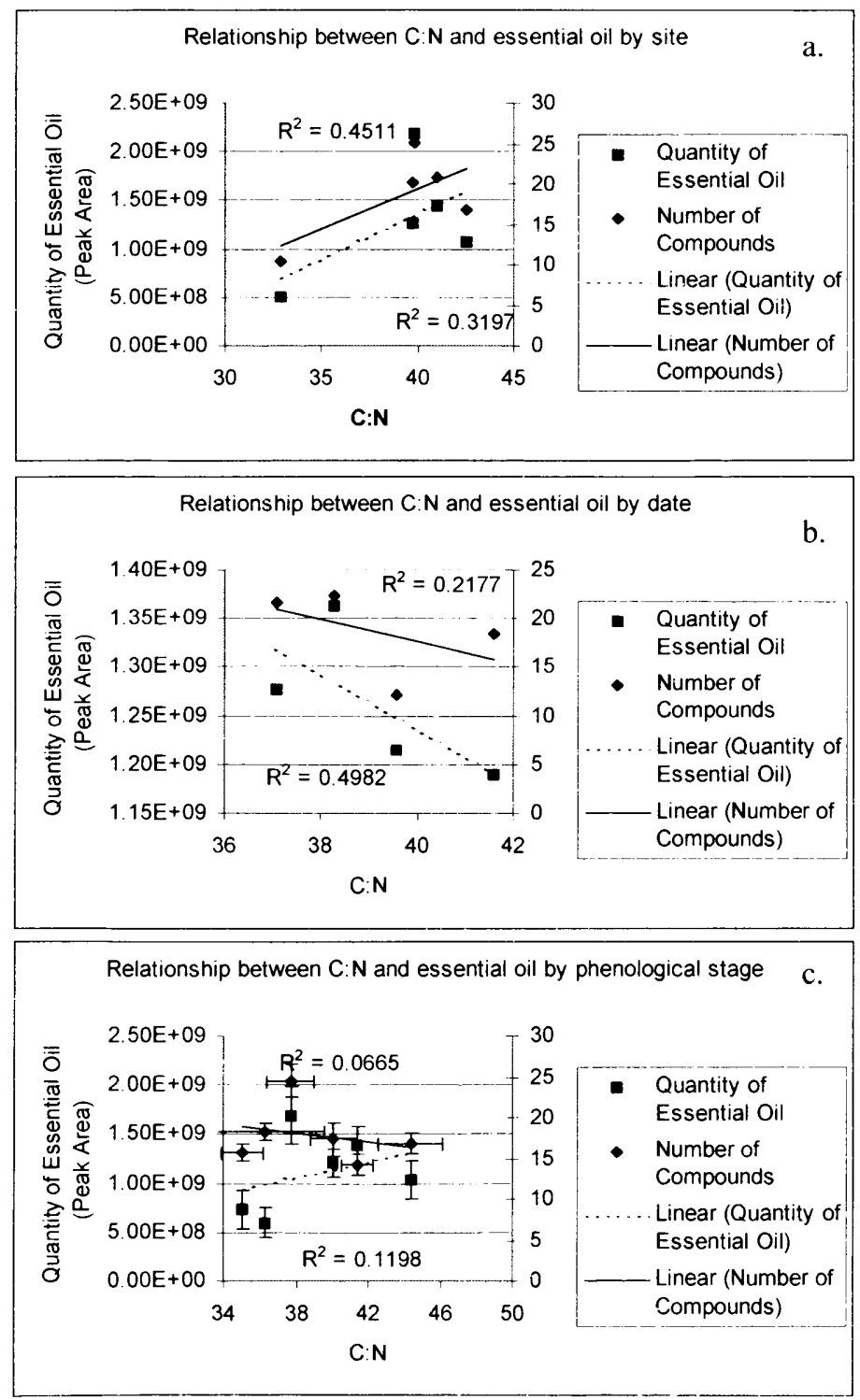
Figure 6. Relationship between foliar $\mathrm{P}$ and the quantity and number of compounds in the essential oil of Ledum palustre ssp decumben by site (Livengood, Finger Mt, Coldfoot, Toolik Lake, and Franklin Bluffs), b: date (June 13, July 01, July 21, Aug 16), and c: phenological stage (Snowfree, bud, flower, flowers senescing, capsules expanding, capsules dehisced). Values are means.
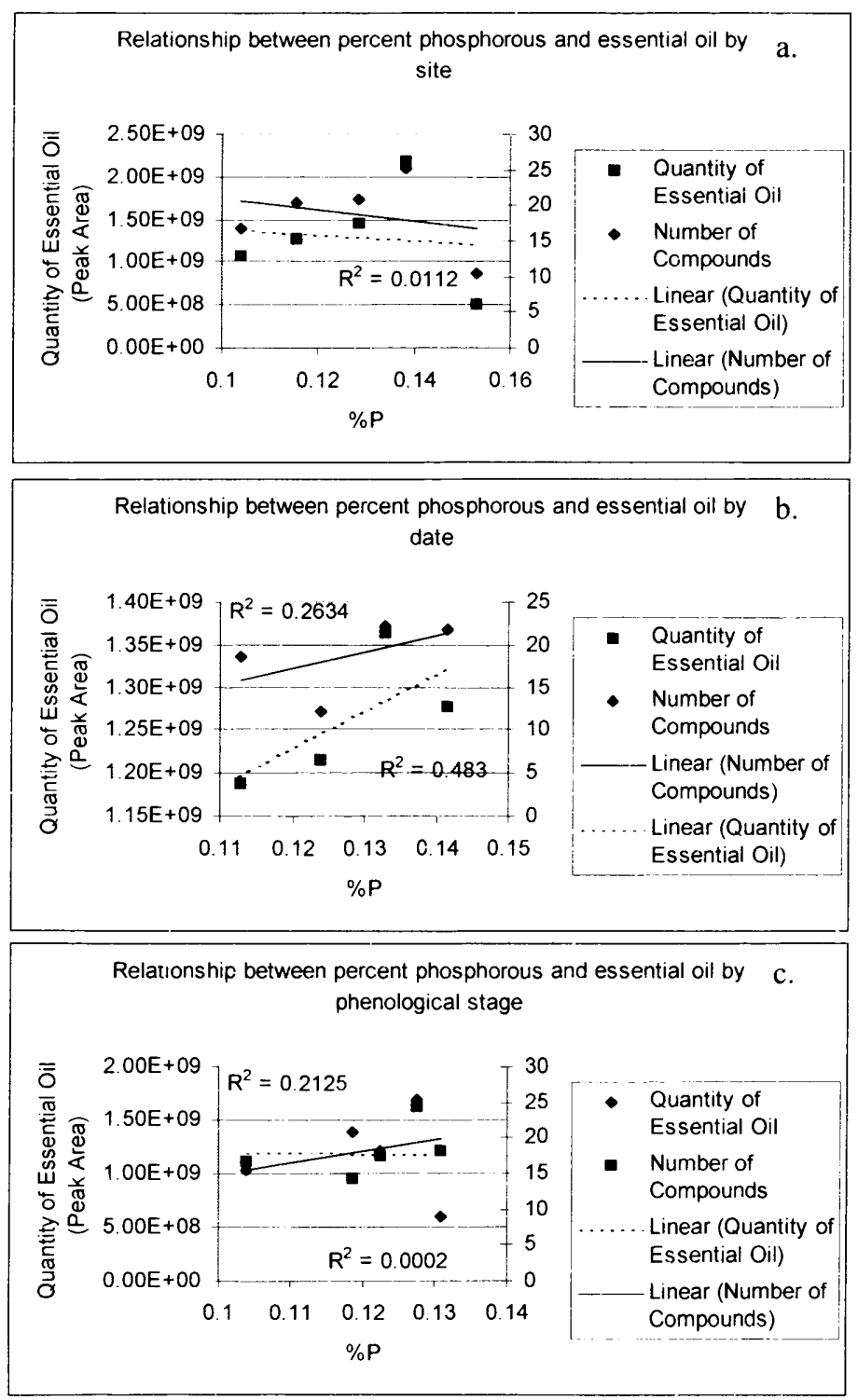
Figure 7: Relationship between the number of compounds (see scale) and the foliar C:N for each site on all collection dates for Ledum paiustre ssp decumbens (Livengood, Finger Mt, Coldfoot, Toolik Lake, and Franklin Bluffs) on 4 dates (June 13, July 01, July 21 , and August 16, 2003). The solid line is the linear relationship between the $\mathrm{C}: \mathrm{N}$ ratio in the leaves and the number of compounds in the essential oil.

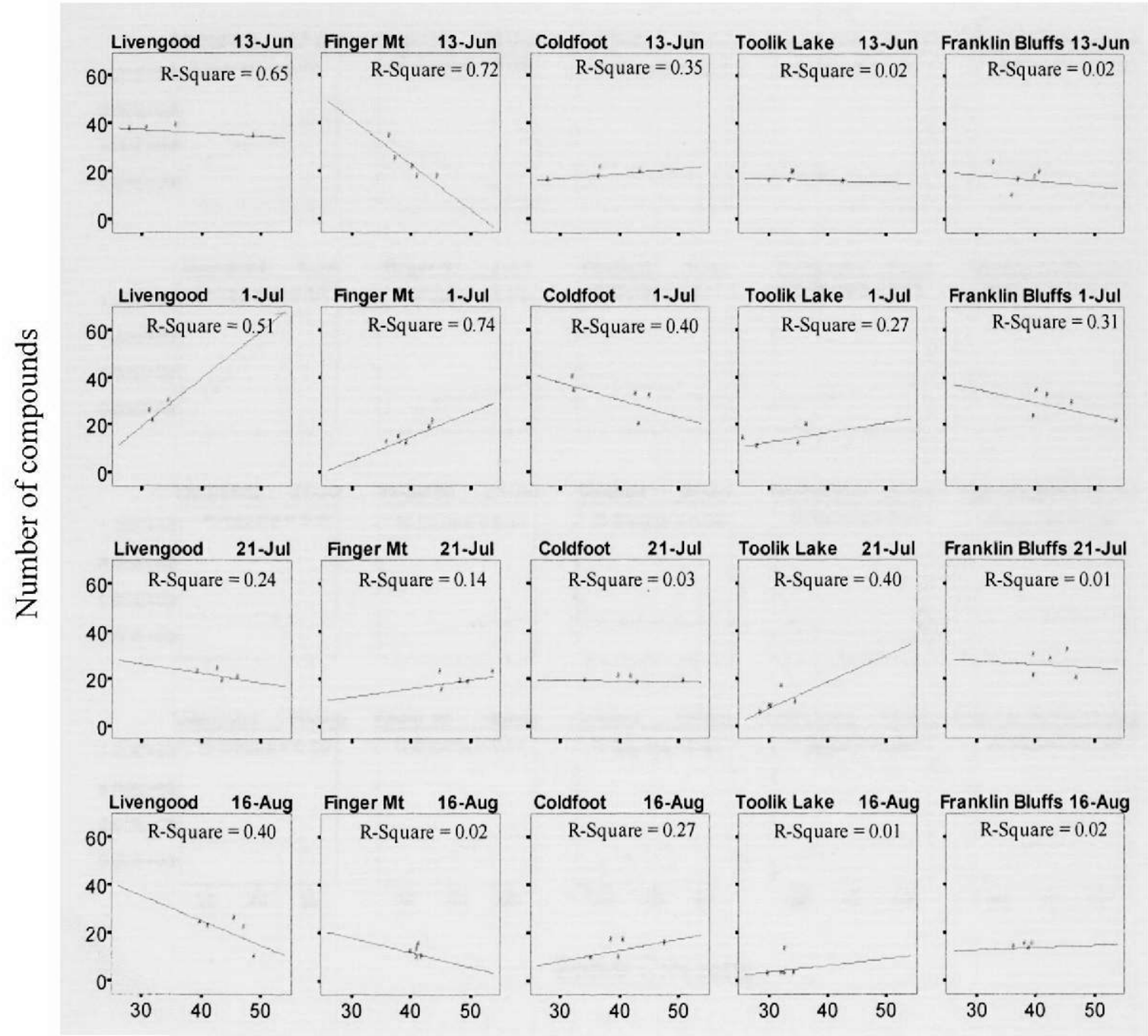

Foliar C:N ratio 
Figure 8: Relationship between the quantity of essential oil and the foliar $\mathrm{C}: \mathrm{N}$ for each site on all collection dates for Ledum palustre ssp decumben (Livengood, Finger Mt, Coldfoot, Toolik Lake, and Franklin Bluffs) on 4 dates (June 13, July 01, July 21, and August 16, 2003). The solid line is the linear relationship between the C:N ratio in the leaves and the quantity of essential oil.

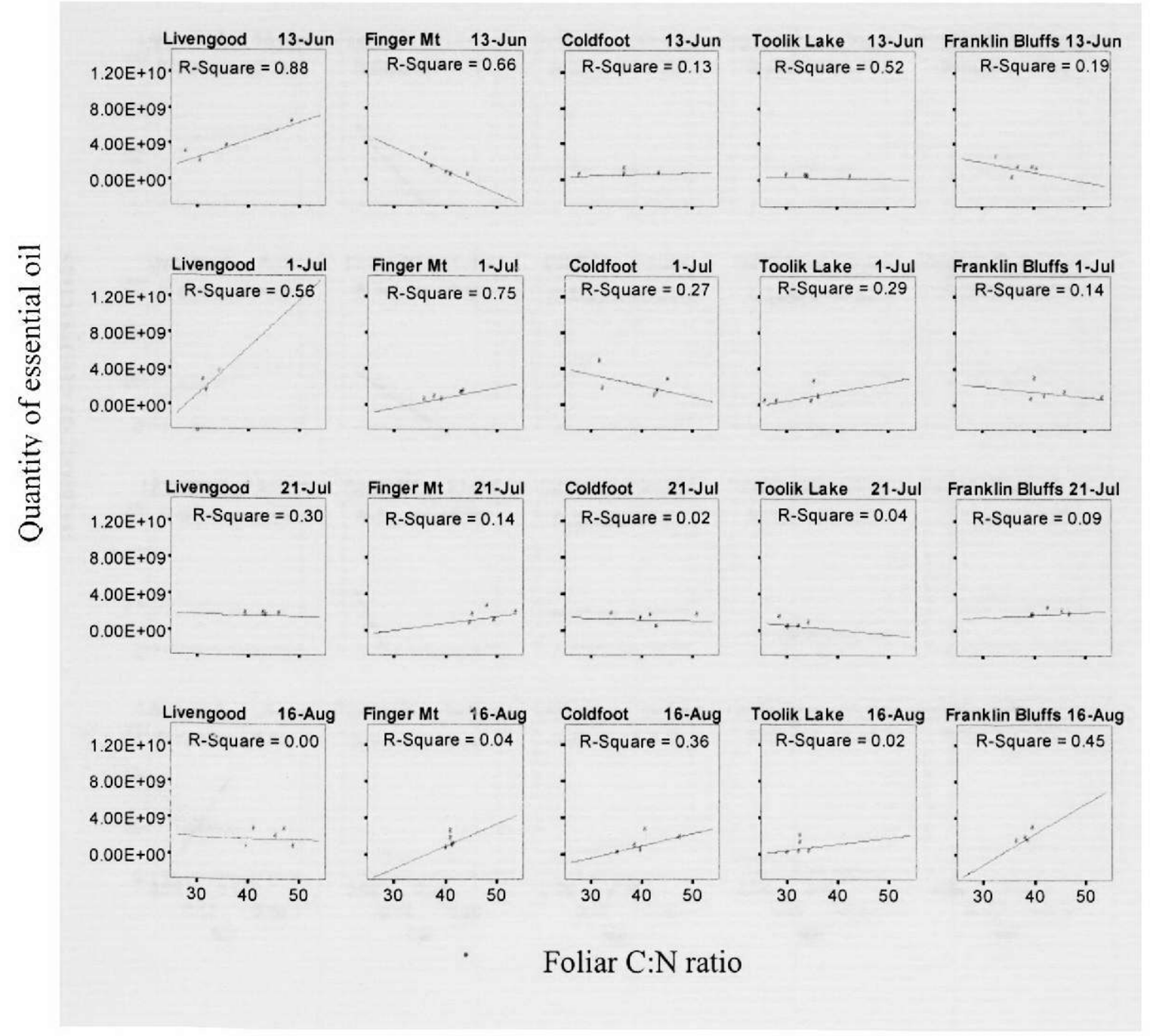


Figure 9. Relationship between the number of compounds (see scale) and the foliar P for each site on all collection dates for Ledum palustre ssp decumbens (Livengood, Finger Mt, Coldfoot, Toolik Lake, and Franklin Bluffs) on 4 dates (June 13, July 01, July 21, and August 16, 2003). The solid line is the linear relationship between percent $\mathrm{P}$ in the leaves and the number of compounds in the essential oil.

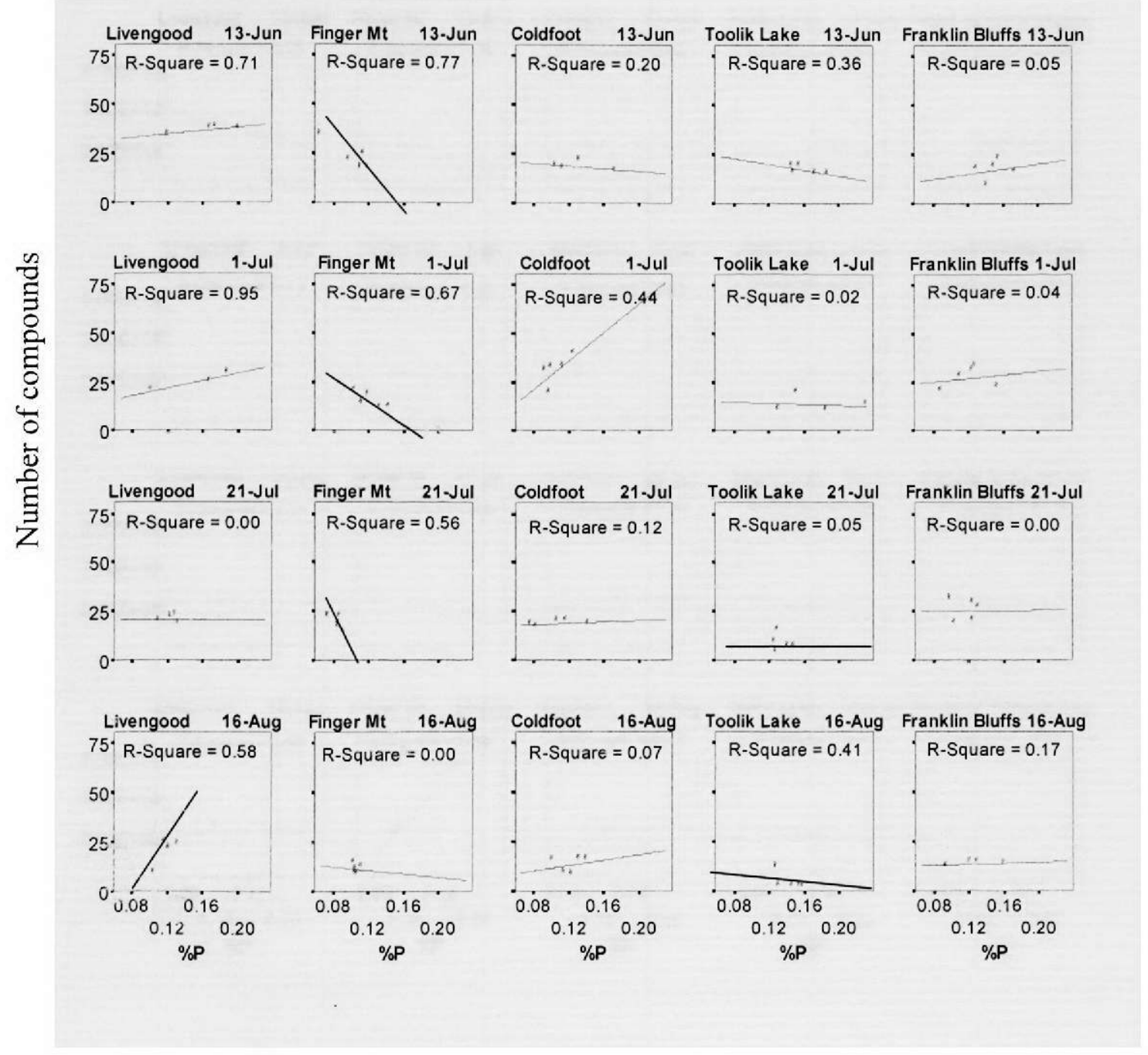


Figure 10: Relationship between the quantity of essential oil and the foliar P for each site on all collection dates for Ledum palustre ssp decumbens (Livengood, Finger Mt, Coldfoot, Toolik Lake, and Franklin Bluffs) on 4 dates (June 13, July 01, July 21, and August 16, 2003). The solid line is the linear relationship between percent $\mathrm{P}$ in the leaves and the quantity of essential oil.

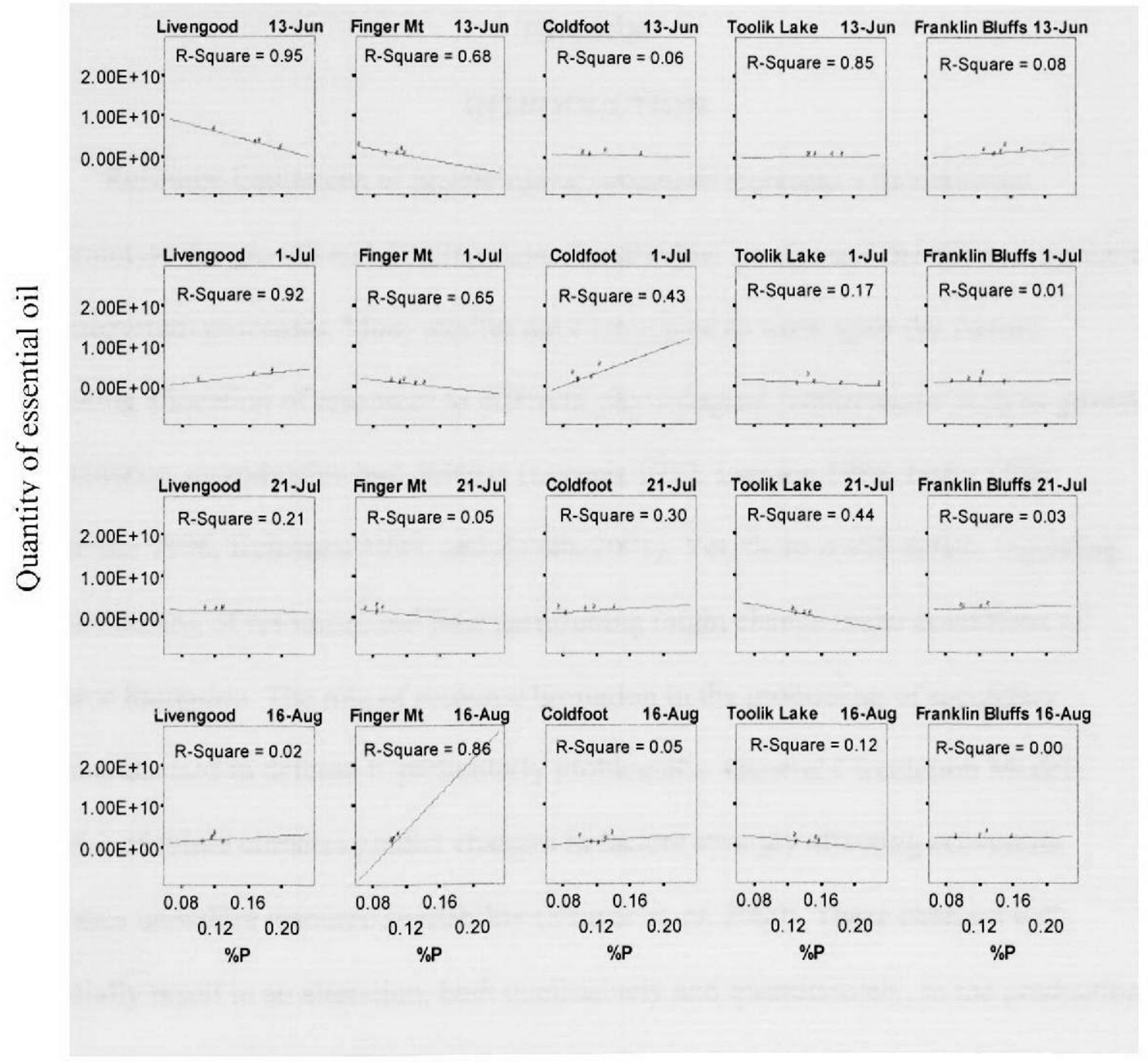




\section{CHAPTER III}

THE EFFECT OF LONG TERM RESOURCE MANIPULATION ON THE

ESSENTIAL OIL PRODUCTION OF L. PALUSTRE SSP DECUMBENS (ALT.)

\section{HULTÉN}

\section{INTRODUCTION}

Resource limitations of physiological processes represent a fundamental constraint on the growth and development of individual species and therefore community and ecosystem processes. Many studies have attempted to tease apart the factors regulating allocation of resources to different physiological requirements such as growth, maintenance, reproduction and defense (Loomis 1932, Larsson 1986, Lorio 1986, Rhoumaki 1996, Keinanen 1999, and Zavala 2001). Yet, there is still debate regarding the partitioning of resources and how partitioning might change under conditions of resource limitation. The role of resource limitation in the production of secondary compounds used in defense is particularly problematic. General Circulation Models (GCMs) of future climates predict changes in factors strongly affecting ecosystem processes including resource availability (Shaver et. al. 2000). These changes will potentially result in an alteration, both qualitatively and quantitatively, in the production of secondary compounds. This variation may affect both the ecological interactions among species and use of commercially important secondary compounds.

The literature is extensive on the variation in secondary compound production (Zangerl 1986, Marquis 1992, Kroicheva et. al. 1998, Keinanen et. al. 1999, and Hamilton et. al. 2000), but there is great variability in the response of different species to 
external factors. For example, the furanocoumarins found in Pastinaca sativa respond most to induced damage, next by genotypic variation and finally to light and nutrient variation (Zangerl 1986 and Hamilton et. al. 2000). Alternatively, the tannin and total phenolic composition of Betula pubescens ssp tortuosa is most affected by fertilization and shade, then by genotype and damage (Ruohomaki et. al. 1996.)

I addressed the role of resource limitation in the production of essential oil by $L$. palustre ssp decumbens (Ait.) Hultén. Economically, the shrub is an important food and medicinal source for circumpolar native peoples. The essential oil of the shrub has uses in medicinal practice as a homeopathic remedy of puncture wounds (especially spider poisonings) and historically in the treatment of coughs, colds, bronchial, and pulmonary disorders by both indigenous and non-indigenous peoples. Current use by native people in Alaska is primarily as a beverage flavoring with historical medicinal use. However, $L$. palustre is mildly toxic due to the sesquiterpene Ledol, a substance that can produce cramps, paralysis, heart palpitations, or a condition referred to as Ledum rheumatism (Walker 1984 and Russels 1991). Changing environmental conditions might affect the composition of the essential oil and thereby affect both native and non-native uses of the plant.

Ecologically, L. palustre ssp decumbens is an important species with a circumpolar distribution, representing up to $50 \%$ of vegetative cover in wet shrub tundra and as a dominant understory shrub in boreal forest. Belleau and Collin (1993) identified multiple terpenoid compounds in the essential oil of Ledum groenlandicum (Ledum palustre ssp groenlandicum). Terpenoid compounds are known allelopathic agents. Inderjit and Malik (1997) identified a change in black spruce (Picea mariana) seedling 
growth with changing soil chemistry resulting from additions of $L$. palustre ssp groenlandicum leaves, suggesting an allelopathic interaction. The importance of both subspecies of $L$. palustre as an allelopathic factor in boreal forest will increase as the timberline encroaches in elevation and latitude towards arctic tundra with increasing global temperatures. In a simulated environmental change experiment, leaf emergence and flowering in L. palustre occurred earlier when the temperature was increased $1.3{ }^{\circ} \mathrm{C}$ over the growing season (Suzuki and Kudo, 1997). This suggests a change in the expression of different secondary compounds with increased global temperature. This might result in a change in the allelopathic effects if the expression of the allelopathic compounds in the essential oil occurs earlier than the establishment of competitor seedlings.

The work presented here aims to increase the understanding of the interaction between resource availability and secondary compound production. This was accomplished by assessing the essential oil component of $L$. palustre ssp decumbens in response to a long-term (14-year) climate change simulation experiment in northern Alaska manipulating light, temperature, and soil nutrients. This experiment allowed for an analysis of the independent and combined effects of specific resources, nitrogen, phosphorus, nitrogen and phosphorus, light, and temperature, on essential oil production and composition. Given that this was a long-term experiment in which many community composition changes had occurred in response to treatment, interpretation of the effects of treatments on Ledum must include potential effects of these community changes, for example shading by dominant overstory plants. To understand the physiological basis for responses to these resources, I combined measurement of photosynthetic rates and 
chlorophyll fluorescence with essential oil analysis. The results of this experiment should provide indications as to essential oil production in a globally changing climate and how those changes are affected by community interactions.

\section{METHODS}

\section{Study Site}

Toolik Field Station is located in the northern foothills of the Brooks Range in Northern Alaska at $68^{\circ} 38^{\prime} \mathrm{N}, 149^{\circ} 38^{\prime} \mathrm{W}$ with an elevation of $720 \mathrm{~m}$. The dominant vegetation in the region is tussock tundra with Eriophorum vaginatum, Ledum palustre ssp decumbens, and Betula nana as codominant species. The growing season is typically mid May to September and has a mean temperature of $7^{\circ} \mathrm{C}$. Daily climatic data for this site were obtained through the Arctic Long Term Ecological Research (LTER) project and the North America International Tundra Experiment (ITEX) at Toolik Field Station.

\section{Treatments}

Ledum palustre ssp decumbens was collected from the Arctic LTER terrestrial experiment at Toolik Lake, AK. These plots are a factorial series of resource manipulations started in 1988 (Chapin 1995). The site consists of four replicate blocks with each block consisting of ten $5 \times 20 \mathrm{~m}^{2}$ plots separated by a $1 \mathrm{~m}$ buffer strip (Figure 1) These ten plots represent control, attenuated light (shade), increased temperature (greenhouses), and nutrient additions (N, P, and NP). Within each block, plots were randomly assigned the following treatments; 14 year nitrogen addition $(\mathrm{N})$, phosphorus addition $(\mathrm{P})$, nitrogen + phosphorus addition $(\mathrm{NP})$, shade $(\mathrm{S})$, shade + nitrogen and phosphorus (SNP), greenhouse warming $(\mathrm{G})$, greenhouse warming + nitrogen and phosphorus (GNP), and controls (C). Attenuated light was achieved using optically 
neutral shade cloth that removes $50 \%$ of the incoming radiation. Temperature was increased using transparent plastic sheeting $(0.15 \mathrm{~mm}$ thickness $)$. Both light attenuation and increased temperature treatments used A- shaped wooden frames with the treatment material stretched over the frames. The A-frames were $10 \mathrm{~cm}$ off the ground to $1 \mathrm{~m}$ tall in the center. Both warming structures (greenhouses) and shade structures (shade houses) were placed on the plots following snow melt each spring and removed before snow accumulation in the fall. Nutrient addition consisted of the application of $10 \mathrm{~g} / \mathrm{m}^{2}$ nitrogen as $\mathrm{NH}_{4} \mathrm{NO}_{3}$ and $5 \mathrm{~g} / \mathrm{m}^{2}$ phosphorus as $\mathrm{P}_{2} \mathrm{O}_{5}$. Further information regarding these plots is available in Chapin et. al. (1995).

\section{Sample Collection and Physiological Measurements}

In these experimental treatments, I sampled six individuals in each of the four replicates of each treatment. Selection of all individuals was haphazardly within a $3 \mathrm{~m}^{2}$ area inside the $100 \mathrm{~m}^{2}$ area of each replicate plot. Each individual was measured for maximum photosynthesis, yield of fluorescence, and dark-adapted fluorescence to assess the physiological status of each plant within the treatments. Maximum photosynthesis $\left(A_{\max }\right)$ was measured using a Li-6400 photosynthesis system (LI-COR Inc., Lincoln, NE) at a photon flux density of $1500 \mu \mathrm{mol} \mathrm{m}^{-2} \mathrm{~s}^{-1}$ and $\mathrm{CO}_{2}$ concentration at $380 \mu \mathrm{mol} \mathrm{mol}{ }^{-1}$. Fluorescence yield determined overall photochemical quantum yield or "yield" of energy conversion under ambient light. Dark-adapted fluorescence determined potential quantum efficiency, using the ratio of variable fluorescence $\left(F_{v}\right)$ to maximum fluorescence $\left(F_{m}\right)$. Fluorescence measurements were made using an OS-5 fluorometer (Opti-sciences, Tyngsboro, MA) 
Following physiological measurements, all aerial parts were immediately

collected and frozen. All collections were on the same day at near peak biomass (July 18) within a 2-hour period to eliminate variation due to either diurnal or seasonal effects. 1 collected the nearest neighbor of each individual and dried the leaves to determine foliar carbon: nitrogen and percent phosphorus for each treatment.

Light and temperature were measured using sensors placed at plant level to determine variation in the environment experienced by the sample plants. Light levels and temperatures at the time of collection for each individual were determined by using a calibrated GaAP photodiode and thermocouple connected to a high-resolution voltmeter (Tenma Multimeter 72-6202, Springboro, OH). Light levels were taken at the angle of the plant leaves.

\section{Plant Nutrient Composition}

Plant nutrient composition was measured for foliar percent phosphorus and the ratio of $\mathrm{C}: \mathrm{N}$. The $\mathrm{C}: \mathrm{N}$ ratio in dried leaf samples were measured using an elemental analyzer (Carlo Erba, Valencia, CA). Percent phosphorus was measured using a molybdate antimony volumetric technique. Samples were weighed, ashed at $800^{\circ} \mathrm{C}$ for 6 hours in a muffle furnace, acidified, and reacted with ammonium molybdate and antimony. The resulting solution was measured using a spectrophotometer (Shimadzu, Columbia, MD).

\section{Essential Oil Analysis}

Essential oil analysis was accomplished using a static headspace sampling technique. To determine the amount of the different components, $0.23 \mathrm{~g}$ of leaves and apical growth stems were placed in a 10-ml headspace autosampler vial. No effort was 
placed on selecting a specific leaf age or quality. Apical growth stems were included in the analysis because preliminary assays determined the prevalence of the essential oil producing hairs on newer stems. The resulting samples contained a mixture of both new and old leaves representative of the plant at the time of collection along with the supporting stems. These samples were heated to $80^{\circ} \mathrm{C}$ for $5 \mathrm{~min}$ to volatilize essential oil components and stabilize the temperature. A $25 \mu \mathrm{l}$ sample of headspace was extracted and analyzed using a gas chromatograph with an attached mass spectrometer (Hewlett Packard 5973 MSD, $0.25 \mu \mathrm{m}$ i.d., $30 \mathrm{~m}, \mathrm{DB}-5$ capillary column). This headspace technique allows for rapid identification and subsequent quantification of the major components in the essential oil while also minimizing the adulteration of the compounds known to occur in other extraction methods. Components were measured using peak area analysis. The compounds with a detectable peak area were qualitatively determined and the most prevalent compounds were measured quantitatively to determine variation among samples. These compounds were $\alpha$ - pinene, $\beta$ - pinene, cymene, camphene, $\gamma$ terpenol, unknown monoterpene $1, \alpha$ - phellandrene, allocymene, unknown sesquiterpene 2, sabinene, unknown sesquiterpene 3 and terpinene.

\section{Statistical Analysis}

Principle component analysis was conducted to attempt to group the essential oil components based on a correlation between compounds. However, no definitive groups could be established and therefore, components were analyzed individually. Two-Way Analysis of variance (ANOVA) was used to determine the interaction between treatment and essential oil variation with light and nutrient and temperature and nutrient as main 
effects in distinct tests. Physiological parameters were also included in the analysis. This variation was then analyzed to determine the relationship between physiological stress and essential oil production using correlation analysis. Multivariate analysis was conducted on all the detectable essential oil components to determine the effect of each treatment on the variation in expression of these secondary compounds. Finally, partial correlation analysis was used to clarify the relationships between nutrients and essential oil component.

\section{RESULTS}

\section{Nutrient Composition}

Nutrient analysis revealed differences among the treatments in percent $\mathrm{P}$ and $\mathrm{C}: \mathrm{N}$ present in the leaves (Table 1). Percent phosphorus in the leaves was significantly lower in the greenhouses (both GC and GNP) than all other treatments. Unlike the GC, the shade control (SC) was not different from the overall control $(\mathrm{C})$, but was different from the other treatments including shade plus nitrogen and phosphorus (SNP). Greenhouse plus nitrogen and phosphorus (GNP) resulted in lower percent phosphorus in the leaves compared to the other phosphorus additions ( $\mathrm{SNP}, \mathrm{CP}$, and $\mathrm{CNP})(\mathrm{F}=54.957, \mathrm{P}<0.001)$. $\mathrm{C}: \mathrm{N}$ ratio was lowest in the Nitrogen addition $(\mathrm{CN})$ and the highest in the $\mathrm{GC}$ treatment. All nitrogen addition treatments had a lower $\mathrm{C}: \mathrm{N}$ than the other treatments except for GNP, which was higher than the SC, CP, and C. However, the percentage of foliar nitrogen in the GC was greater than that of all other treatments including the GNP (data not shown, $\mathrm{F}=38.873, \mathrm{P}<0.001)$. 


\section{Physiological and Morphological Variation}

$\mathrm{A}_{\max }$ was different among the treatments with SNP exhibiting a reduced

photosynthetic potential of more than half that of the $\mathrm{GC}$ (Table 2, $\mathrm{F}=3.995, \mathrm{P}=0.001$ ). $\mathrm{A}_{\max }$ in the SC was $57 \%$ greater than that in the SNP and in every instance, the nutrient treatment was higher than that treatment's control treatment (for example, SC is lower than $\mathrm{SNP}, \mathrm{C}$ is lower than $\mathrm{CNP}$, Table 2). Increased temperature resulted in a higher $\mathrm{A}_{\max }$ $(\mathrm{F}=6.138, \mathrm{P}=0.016)$. Neither the reduced light treatment $(\mathrm{F}=3.509, \mathrm{P}=0.066)$ or nutrient additions $(\mathrm{F}=1.568, \mathrm{P}=0.215)$ resulted in an effect upon $\mathrm{A}_{\max }$ (Table 3$)$. Analysis of fluorescence measurements also revealed effects of the treatments (Table 2). The addition of phosphorus alone resulted in a lower yield of fluorescence compared to that in the $\mathrm{CNP}$ and $\mathrm{C}$ (Table 2, $\mathrm{F}=4.479, \mathrm{P}=0.038$ ). Yield of fluorescence increased due to the interaction of nitrogen and phosphorus additions $(\mathrm{F}=12.429, \mathrm{P}=0.001)$. The ratio between variable fluorescence and maximum fluorescence $\left(F_{v} / F_{m}\right)$ for dark-adapted leaves was not affected by the increased temperature or reduced light treatments but was affected by the interaction of nitrogen and phosphorus additions $(\mathrm{F}=4.563, \mathrm{P}=0.036)$. The addition of nutrients affected average leaf size when coupled with a decrease in light $(\mathrm{F}=9.455$, $\mathrm{P}=0.003$ ) and an increase in temperature (Table 3, Figure 2, $\mathrm{F}=5.544, \mathrm{P}=0.022$ ).

\section{Essential Oil Quantity and Composition}

The essential oil components tested varied greatly with differences in the quantity of essential oil across treatments $(\mathrm{F}=2.328, \mathrm{P}=0.028)$. The quantity of essential oil in the headspace was lowest in $\mathrm{CP}$ and highest in both the $\mathrm{C}$ and CNP (Figure 3).

An average of 17 components was detectable at greater than trace levels in the headspace of L. palustre ssp decumbens for all treatments (Table 4). SNP had the lowest 
number of compounds (12) and CNP had the highest number of compounds (22). The overall variance across all treatments was not found to be significant $(\mathrm{F}=1.708, \mathrm{P}=0.112)$.

When these components were examined independently, several compounds were found to be driving the variation in the quantity of essential oil. Unknown monoterpene 3 , $\alpha$ - phellandrene, cymene, unknown 8 , sabinene, and terpinenol did not affect the relationship of the treatments to the essential oil. This effect of the treatments on the essential oil was partly explained through partial correlations, with camphene $\left(R^{2}=0.208\right.$, allocymene $\left(\mathrm{R}^{2}=0.188\right)$, and unknown $6\left(\mathrm{R}^{2}=0.138\right)$ as the strongest factors (Figure 5). This is mostly the result of the three being detectable in very small amounts in the greenhouse treatments (GC and GNP) compared to the other treatments (Figure 6). Unknown monoterpene 2 also explained over $18 \%$ of the variance, but the causality was not as clear. The $\mathrm{C}, \mathrm{CN}$, and $\mathrm{CNP}$ treatments had higher quantities of unknown 2 compared to the GC and SC although neither of the two was different from its respective nutrient addition (GNP and SNP).

The number of compounds was positively correlated to the foliar percent phosphorus (Pearson Correlation $=0.207, \mathrm{P}=0.013$ ) and negatively correlated to the $\mathrm{C}: \mathrm{N}$ ratio in the leaves (Pearson Correlation=-0.263, $\mathrm{P}=0.002$ ). The number of compounds was weakly negatively correlated to $F_{v} F_{m}$ (Pearson Correlation=-0.58). There was also a negative relationship between the number of terpenes found and the $A_{\max }$ (Pearson Correlation $=-0.270, \mathrm{P}=0.002$ ). The quantity of essential oil did not correlate with the nutrients in the leaves or the physiological parameters measured across treatments, nor was there a correlation between the quantity of essential oil and the number of compounds in the essential oil. When data were analyzed further using a two-way 
ANOVA (Table 4), the quantity of essential oil was affected by reduced light $(\mathrm{F}=5.484$. $\mathrm{P}=.023)$ but not by increased temperature $(\mathrm{F}=1.695, \mathrm{P}=0.198)$ or the addition of nitrogen alone $(\mathrm{F}=2.831, \mathrm{P}=0.097)$. The quantity of terpenes decreases $(>80 \%)$ with the addition of only phosphorus ( $\mathrm{T}$-test $\mathrm{F}=3.884, \mathrm{~d} f=38, \mathrm{P}=0.001$ ). The number of compounds was found to be reduced only by the reduction in light $(\mathrm{F}=7.361, \mathrm{P}=0.009)$, and unlike the quantity of essential oil, does not seem to be as negatively affected by the addition of phosphorus alone (though there is a significant difference in the number of compounds in CP verses the $\mathrm{C})$.

\section{DISCUSSION}

1 found striking effects of resource manipulation on the essential oil production of Ledum palustre ssp decumbens. Shading and the addition of phosphorus both resulted in large reductions $(>80 \%)$ in the quantity of essential oil. This result is likely related to physiological effects of these treatments, both of which caused substantial reductions in photosynthetic capacity. For example, the phosphorus addition treatment was significantly lower than the control for yield of fluorescence, had the lowest $F_{v} / F_{m}$ and had low $\mathrm{A}_{\max }$. These results suggest that although the addition of $\mathrm{P}$ alone did not change $\mathrm{N}$ levels, it disturbed the nutrient balance of other non- $\mathrm{N}$ or $\mathrm{P}$ nutrients in Ledum either directly or through the action of competing plants. Previous work has shown an increase in $A_{\max }$ with the addition of $\mathrm{N}$ (Lerdau 1992), yet it is unclear from this study if $A_{\max }$ would decrease in response to nitrogen limitation. Bigger and Oechel (1982) reported reduced $\mathrm{A}_{\max }$ in tundra plants in response to NPK fertilization, a finding they proposed was a result of the dilution of other essential nutrients by increased growth resulting from NPK fertilization. The SC treatment had the lowest $A_{\max }$ of all the treatments. The results 
from the $\mathrm{SC}$ and $\mathrm{P}$ treatments suggest that reductions in essential oil quantity are a function of carbon availability.

The variation in the leaf nutrients suggests the treatments are indeed affecting the availability of those resources to the plants. Because the nutrient treatments were not uniformly different from the control treatments, the relationship between essential oil variation and nutrient availability is not straightforward. Rather, there is an interaction between nutrients and some other factors (Shaver et. al. 2000). The higher C:N and lower $\mathrm{P}$ in the leaves of plants in the $\mathrm{GC}$ treatments suggests that the increased temperature is affecting the ability of the plant to sequester these nutrients or is allowing increased growth that is diluting the leaf tissue concentrations. These results might be a consequence of community interactions caused by changes in the dominant vegetation. Lower tissue nutrients may also suggests that the greenhouse treatments should have a decrease in secondary compounds due to the increased competition and naturally occurring limitations in resources. While the quantity of essential oil was not the highest in the greenhouses, it was also not the lowest and other factors such as increased temperature and a decrease in the number of compounds might be the cause. The absence of some of the compounds in the greenhouse treatments suggests that the increased temperature treatment resulted in volatilization of these compounds or the precursor compounds (Tatro 1973). There is a noticeable increase in volatile compounds in the greenhouse environment, so this result was not all together unexpected. However, this suggests that temperature increases of this magnitude will result in the increased volatilization of the compounds or their precursors that might act in allelopathic effects, as herbivore defenses, or those compounds that make the plant valuable as a medicinal/ 
food source. This might trigger increased community changes, further confounding the effect of increased temperatures.

Both the $\mathrm{C}$ and $\mathrm{CNP}$ treatment had the highest amount of extractable oil suggesting that expression of oil production is not a direct function of nitrogen availability; the $\mathrm{CNP}$ treatment had a much lower $\mathrm{C}: \mathrm{N}$ than the $\mathrm{C}$ while the $\mathrm{CN}$ treatment presented less extractable oil. The $\mathrm{C}: \mathrm{N}: \mathrm{P}$ balance presents an important regulating factor in the general physiological status of the plant (Loomis 1932, Larsson 1986, Lorio 1986, Rhoumaki 1996, and Zavala 2001). When phosphorus is supplied without nitrogen, both the physiological measurements and the essential oil parameters decrease following a disruption of the C:N:P balance (Loomis 1932). Similarly, the addition of nitrogen alone results in a decrease in the measured parameters of essential oil and physiology. In contrast, the addition of both nitrogen and phosphorus does not result in either a significant change in either essential oil production or physiological measurement from the control. In this instance, the addition of phosphorus alone is suppressing the photosynthetic capacity of Ledum while nitrogen alone is increasing it. The combination of the two nutrients in the CNP treatment slightly increased the physiological potential from the $\mathrm{C}$ and $\mathrm{CN}$ treatments. Increased levels of resources will typically result in increased productivity (Crane and Banks I992, McCullough et. al. 1993, and McNulty and Aber 1993).

Analysis of the physiological factors revealed significant differences among treatments, but in ways unexpected for simple resource manipulations. As these measurements were taken in the $14^{\text {th }}$ year of the experiment, it is very likely that the resource manipulations have altered the community composition to such an extent that 
resources available to Ledum, including resources that were not intentionally manipulated, declined in some treatments relative to those in the controls. These factors might include decreased light levels, increased denitrification, or water stress (Shaver. personal communication). While some light attenuation might be expected as a factor in a greenhouse warming treatment because of the greenhouse plastic, the change in species composition with just the addition of nutrients resulted in less light at Ledum leaf level than in the shade plus nutrients (Figure 2). Furthermore, as a result of these canopy changes, Ledum has increased in height. Community changes within the SNP were to the point of near complete exclusion of all species but Rubus chamemorous, and the GNP and $\mathrm{GC}$ have increased the growth of the two dominant deciduous species, Betula nana and Salix pulchra such that Ledum was shaded within the middle to lower canopy of the increased deciduous shrubs. The effects of these community composition changes are likely confounding the observed treatment effects presented here.

The physiological measurements served as a means of monitoring the treatment caused effects on the study species, reducing the potential of misinterpretation of the cause of essential oil variation. It is possible that specific treatments, such as the greenhouse controls $(\mathrm{GC})$, are supporting increased productivity and maximizing physiological processes and therefore specific compounds (like cymene in $\mathrm{GC}$ ) are increased while others are decreased. The relationship between nutrients and leaf size is not entirely clear since the control treatment did not vary significantly from the nutrient addition treatments. This suggests nutrient addition affects leaf area in the increased temperature and decreased light treatments, but not necessarily because of nutrient availability. Leaf size in plants typically increases under reduced light as a response to 
maximize light capture (Jackson 1966). That leaf sizes in the SC treatment were not different than $\mathrm{C}$ suggests that other factors are overriding the shade response.

In contrast to the findings of the transect study where the number of compounds was positively correlated to production of total essential oils (Chapter II), no such relationship was found in response to resource limitation treatments in this study. Nor were strong relationships found between leaf tissue nutrients and the number or quantity of compounds as seen in the transect study. These results suggest that as a result of the manipulation of individual resources, the connection between the number and quantity of essential oils can be decoupled. The negative relationship found between $F_{v} F_{m}$ and the number of compounds suggests generally that plants with higher stress levels as indicated by lower $\mathrm{F}_{\mathrm{v}} \mathrm{F}_{\mathrm{m}}$ tend to make more compounds. The number and quantity of compounds were also strongly reduced in the shade treatments. An important finding of this research was that the individual components of the essential oil were in many cases affected differently by the treatments. Whether these responses are a direct result of the resource manipulation is unclear. The synthesis pathways of these chemicals may be such that the effects of $\mathrm{N}$ and $\mathrm{P}$ on the specific compounds are the basis of the changes seen here.

The work presented here aimed to increase the understanding of resources availability on the production and composition of essential oil of a model species. Ledum palustre ssp decumbens. While definitive picture is not available, it is clear that changes in nutrient composition and light environment will result in changes in the essential oil expression of this species. Whether these changes are the result of direct effects of increases or decreases of specific nutrients, community composition changes. changes in competitive balance, or some other factor is unclear. Climate changes will undoubtedly 
be accompanied by the changes mentioned above. This work has shown that essential oil production will respond as well. Further work is required to tease apart these factors to determine how they are intertwined within the regulating factors behind essential oil expression. 
Table 1. Leaf tissue nutrients of Ledum palustre ssp decumbens by Treatment $(\mathrm{C}=$ control, $\mathrm{GC}=$ Greenhouse, $\mathrm{GNP}=$ Greenhouse + Nitrogen + Phosphorus, $\mathrm{CN}=$ Nitrogen . $\mathrm{CNP}=$ Nitrogen + Phosphorus, $\mathrm{CP}=$ Phosphorus, $\mathrm{SC}=$ Shade, $\mathrm{SNP}=$ Shade + Nitrogen + Phosphorus.) Values are mean \pm SE. Within a column, means with the same superscript are not significantly different at $\mathrm{P}>0.05$ using comparison of means within a one-way ANOVA. $\mathrm{N}=4$ per treatment. All measurements were arcsine squareroot transformed.

\begin{tabular}{ccc}
\hline & \multicolumn{2}{c}{ NUTRIENT } \\
\cline { 2 - 3 } TREATMENT & C:N & $\mathrm{P}$ \\
\hline C & $30.4 \pm 0.22^{\mathrm{b}}$ & $0.147 \pm .014^{\mathrm{b}}$ \\
GC & $38.3 \pm 1.39^{\mathrm{c}}$ & $0.131 \pm .014^{\mathrm{a}}$ \\
GNP & $31.1 \pm 1.05^{\mathrm{b}}$ & $0.192 \pm .014^{\mathrm{c}}$ \\
CN & $21.9 \pm 0.48^{\mathrm{a}}$ & $0.187 \pm .014^{\mathrm{c}}$ \\
CNP & $22.7 \pm 0.43^{\mathrm{a}}$ & $0.261 \pm .014^{\mathrm{a}}$ \\
CP & $30.1 \pm 1.23^{\mathrm{b}}$ & $0.242 \pm .014^{\mathrm{e}}$ \\
SC & $28.5 \pm 0.57^{\mathrm{b}}$ & $0.153 \pm .014^{\mathrm{b}}$ \\
SNP & $24.1 \pm 0.70^{\mathrm{a}}$ & $0.215 \pm .016^{\mathrm{d}}$ \\
& & \\
\hline
\end{tabular}

Table 2. Physiological status of Ledum palustre ssp decumbens by Treatment $(\mathrm{C}=$ control, GC $=$ Greenhouse control, GNP $=$ Greenhouse + Nitrogen + Phosphorus, $\mathrm{CN}=$ Nitrogen, $\mathrm{CNP}=$ Nitrogen + Phosphorus, $\mathrm{CP}=$ Phosphorus, $\mathrm{SC}=$ Shade control, $\mathrm{SNP}=$ Shade + Nitrogen + Phosphorus). Values are mean \pm SE. Within a row, means with the same superscript are not significantly different at $p>0.05$ using comparison of means within a one-way ANOVA. $\mathrm{N}=4$ per treatment.

\begin{tabular}{cccc}
\hline & \multicolumn{3}{c}{ PHYSIOLOGICAL MEASUREMENTS } \\
\cline { 2 - 4 } TREATMENT & Fv/Fm & Yield & $A_{\max }$ \\
\hline C & $0.715 \pm 0.010^{\mathrm{abc}}$ & $0.498 \pm 0.030^{\mathrm{b}}$ & $1.644 \pm 0.309^{\mathrm{a}}$ \\
GC & $0.729 \pm 0.011^{\mathrm{abc}}$ & $0.483 \pm 0.035^{\mathrm{b}}$ & $2.796 \pm 0.309^{\mathrm{a}}$ \\
GNP & $0.711 \pm 0.010^{\mathrm{ab}}$ & $0.406 \pm 0.030^{\mathrm{ab}}$ & $2.909 \pm 0.363^{\mathrm{a}}$ \\
CN & $0.701 \pm 0.010^{\mathrm{ab}}$ & $0.443 \pm 0.030^{\mathrm{ab}}$ & $2.178 \pm 0.362^{\mathrm{a}}$ \\
CNP & $0.728 \pm 0.01^{\mathrm{abc}}$ & $0.456 \pm 0.035^{\mathrm{ab}}$ & $1.767 \pm 0.309^{\mathrm{a}}$ \\
CP & $0.690 \pm 0.010^{\mathrm{a}}$ & $0.324 \pm 0.030^{\mathrm{a}}$ & $1.714 \pm 0.309^{\mathrm{a}}$ \\
SC & $0.748 \pm 0.020^{\mathrm{bc}}$ & $0.447 \pm 0.063^{\mathrm{ab}}$ & $1.340 \pm 0.363^{\mathrm{a}}$ \\
SNP & $0.764 \pm 0.020^{\mathrm{c}}$ & $0.534 \pm 0.063^{\mathrm{b}}$ & $2.055 \pm 0.451^{\mathrm{a}}$ \\
\hline
\end{tabular}


Table 3. Results from Two-way ANOVA for effect of treatments on physiological and morphological measurements in Ledum palustre ssp decumbens. Treatments were light. Nutrient and the interaction of Light and Nutrient, Temperature, Nutrient and the interaction of Temperature and Nutrient, and Nitrogen Addition, Phosphorus addition and the interaction of both Nitrogen and Phosphorus.

\begin{tabular}{cccccccccc}
\hline & & \multicolumn{2}{c}{ Leaf Size } & \multicolumn{2}{c}{ Fv/Fm } & \multicolumn{3}{c}{ Yield } & \multicolumn{3}{c}{$\mathrm{A}_{\max }$} & \\
\hline Effect & $\mathrm{df}$ & $\mathrm{F}$ & $\mathrm{P}$ & $\mathrm{F}$ & $\mathrm{P}$ & $\mathrm{F}$ & $\mathrm{P}$ & $\mathrm{F}$ & $\mathrm{P}$ \\
\hline Light & 1 & .036 & .851 & 1.83 & .184 & 6.07 & .018 & 3.51 & .066 \\
Nutrient & 1 & 9.45 & .003 & .382 & .540 & 1.09 & .303 & 12.51 & .001 \\
Light* Nutrient & 1 & 1.68 & .200 & 1.01 & .322 & .477 & .494 & 2.60 & .112 \\
Corrected Model LN & 3 & 1.035 & .383 & 1.716 & .172 & 7.483 & .001 & 1.571 & .205 \\
& & & & & & & & & \\
Temperature & 1 & .046 & .831 & .094 & .760 & 1.12 & .294 & 6.14 & .016 \\
$\quad$ Nutrient & 1 & .328 & .568 & .013 & .908 & 1.21 & .276 & 1.08 & .303 \\
Temperature*Nutrient & 1 & 5.50 & .022 & .191 & .664 & .372 & .544 & .543 & .464 \\
Corrected Model TN & 3 & 1.959 & .127 & .097 & .962 & 1.028 & .386 & 2.687 & .053 \\
& & & & & & & & & \\
$\quad$ Nitrogen & 1 & .451 & .504 & .991 & .323 & 2.32 & .132 & .371 & .544 \\
Phosphorus & 1 & 2.05 & .157 & .111 & .740 & 4.48 & .038 & 3.45 & .067 \\
Nitrogen* Phosphorus & 1 & .675 & .414 & 4.56 & .036 & 12.4 & .001 & 1.57 & .215 \\
Corrected Model NP & 3 & 1.057 & .372 & 1.857 & .145 & 6.736 & .000 & 1.796 & .156 \\
\hline
\end{tabular}

Table 4. Results from Two-way ANOVA for effect of treatments on essential oil variation in Ledum palustre ssp decumbens. Treatments were Light, Nutrient and the interaction of Light and Nutrient, Temperature, Nutrient and the interaction of Temperature and Nutrient, and Nitrogen Addition, Phosphorus addition and the interaction of both Nitrogen and Phosphorus.

\begin{tabular}{cccccc}
\hline & \multicolumn{2}{c}{$\begin{array}{c}\text { Essential Oil } \\
\text { Quantity }\end{array}$} & \multicolumn{2}{c}{$\begin{array}{c}\text { Number of } \\
\text { Compounds }\end{array}$} \\
\hline Effect & $\mathrm{df}$ & $\mathrm{F}$ & $\mathrm{P}$ & $\mathrm{F}$ & $\mathrm{P}$ \\
\hline Light & 1 & 5.48 & .023 & 7.36 & .009 \\
Nutrient & 1 & .394 & .532 & .208 & .650 \\
Light* Nutrient & 1 & .408 & .525 & .375 & .543 \\
Corrected Model LN & 3 & 4.371 & .007 & 1.844 & .148 \\
& & & & & \\
Temperature & 1 & 2.50 & .118 & .723 & .398 \\
$\quad$ Nutrient & 1 & .001 & .971 & 2.86 & .095 \\
Temperature*Nutrient & 1 & .002 & .962 & .311 & .579 \\
Corrected Model TN & 3 & .833 & .480 & 1.299 & .281 \\
& & & & & \\
$\quad$ Nitrogen & 1 & 2.83 & .097 & 1.98 & .164 \\
$\quad$ Phosphorus & 1 & 2.87 & .094 & .136 & .714 \\
Nitrogen* Phosphorus & 1 & 4.21 & .044 & .619 & .434 \\
Corrected Model NP & 3 & 3.304 & .025 & .910 & .440 \\
\hline
\end{tabular}


Table 5. Variation in the percentage of each compound in the essential oil components in Ledum palustre ssp decumbens by treatment $(\mathrm{C}=\mathrm{Control}, \mathrm{GC}=$ Greenhouse control, $\mathrm{GNP}=$ Greenhouse + Nitrogen + Phosphorus, $\mathrm{CN}=$ Nitrogen, $\mathrm{CNP}=\mathrm{Nitrogen}+$ Phosphorus, $\mathrm{CP}=$ Phosphorus, $\mathrm{SC}=$ Shade control, $\mathrm{SNP}=$ Shade + Nitrogen + Phosphorus). Values are mean $\pm \mathrm{SE}$. Within a row, means with the same superscript are not significantly different at $\mathrm{P}>0.05$ using comparison of means within a one-way ANOVA. $\mathrm{N}=4$ per treatment.

\begin{tabular}{ccccccccccc}
\hline Rt & Compound & $\mathrm{C}$ & $\mathrm{GC}$ & $\mathrm{GNP}$ & $\mathrm{CN}$ & $\mathrm{CP}$ & $\mathrm{CNP}$ & $\mathrm{SC}$ & $\mathrm{SNP}$ \\
\hline No. of Compounds & $18 \pm 3$ & $14 \pm 2$ & $21 \pm 3$ & $20 \pm 3$ & $15 \pm 3$ & $21 \pm 3$ & $12 \pm 1$ & $12 \pm 2$ \\
4 & $\alpha$ - pinene & $6.36 \pm 1.24$ & $3.24 \pm .550$ & $3.91 \pm .500$ & $5.12 \pm .800$ & $2.77 \pm .660$ & $7.29 \pm .830$ & $8.62 \pm 1.58$ & $2.31 \pm .800$ \\
4.2 & camphene & $8.31 \pm 2.21$ & $1.38 \pm .410$ & $1.30 \pm .330$ & $6.36 \pm 1.51$ & $2.94 \pm 1.16$ & $8.10 \pm 1.75$ & $9.09 \pm 2.94$ & $.402 \pm .272$ \\
4.6 & unknown 1 & $.322 \pm .230$ & $.792 \pm .286$ & $1.40 \pm .520$ & $.467 \pm .197$ & $.708 \pm .354$ & $.763 \pm .280$ & $.145 \pm .145$ & $3.99 \pm 1.13$ \\
4.7 & $\beta$-pinene & $6.72 \pm 1.07$ & $3.55 \pm .943$ & $5.70 \pm .847$ & $5.64 \pm .900$ & $3.95 \pm .910$ & $6.86 \pm .514$ & $6.39 \pm .978$ & $.036 \pm .036$ \\
5.2 & $\alpha$-phellandrene & $.288 \pm .177$ & $.401 \pm .281$ & $.0275 \pm .017$ & $.123 \pm .0400$ & $.045 \pm .021$ & $.153 \pm .093$ & $0 \pm .0$ \\
5.4 & allocymene & $5.84 \pm 1.25$ & $2.09 \pm .99$ & $1.72 \pm .660$ & $3.48 \pm .800$ & $6.03 \pm 3.30$ & $9.73 \pm 1.60$ & $13.42 \pm 5.30$ & $9.66 \pm 3.50$ \\
5.6 & cymene & $47.8 \pm 6.10$ & $55.9 \pm 2.71$ & $51.6 \pm 4.23$ & $42.0 \pm 4.90$ & $51.3 \pm 5.30$ & $35.7 \pm 2.99$ & $39.8 \pm 4.32$ & $56.3 \pm 3.58$ \\
5.7 & unknown 2 & $2.27 \pm .820$ & $1.007 \pm .57$ & $2.34 \pm .810$ & $3.23 \pm .850$ & $0 \pm 0$ & $.572 \pm .410$ & $0 \pm 0$ & $0 \pm 0$ \\
5.8 & unknown8 & $11.2 \pm 2.68$ & $20.6 \pm 4.06$ & $12.7 \pm 2.65$ & $13.7 \pm 4.01$ & $16.5 \pm 3.94$ & $9.65 \pm 2.21$ & $11.7 \pm 3.24$ & $17.3 \pm 3.23$ \\
6.3 & sabinene & $1.86 \pm .432$ & $1.35 \pm .419$ & $2.17 \pm .433$ & $2.17 \pm .511$ & $1.33 \pm .537$ & $2.53 \pm .410$ & $1.49 \pm .476$ & $1.16 \pm .420$ \\
9.3 & unknown 3 & $.110 \pm .080$ & $.220 \pm .200$ & $.025 \pm .020$ & $.054 \pm .038$ & $.271 \pm .271$ & $.199 \pm .199$ & $0 \pm 0$ & $0 \pm 0$ \\
10.1 & terpinen-4-ol & $2.36 \pm 1.46$ & $1.363 \pm .962$ & $4.52 \pm 1.95$ & $2.78 \pm .750$ & $1.72 \pm .815$ & $4.09 \pm 1.51$ & $1.49 \pm .814$ & $0 \pm 0$ \\
10.5 & unknown5 & .463 & $.725 \pm .252$ & $1.32 \pm .330$ & $1.17 \pm .250$ & $.483 \pm .180$ & $.719 \pm .240$ & $.632 \pm .280$ & $0 \pm 0$ \\
11.1 & unknown6 & $2.88 \pm .800$ & $.352 \pm .16$ & $.561 \pm .180$ & $3.07 \pm .970$ & $1.47 \pm .590$ & $4.02 \pm 1.11$ & $1.41 \pm .410$ & $1.17 \pm .410$ \\
11.7 & terpinene & $3.22 \pm 1.07$ & $8.17 \pm 1.89$ & $11.8 \pm 1.90$ & $11.4 \pm 1.85$ & $10.0 \pm 3.17$ & $7.03 \pm 1.49$ & $5.57 \pm 1.99$ & $3.30 \pm 1.53$ \\
& $n$ & 20 & 20 & 20 & 20 & 20 & 20 & 13 & 10 \\
\hline
\end{tabular}


Figure 1. Site experimental layout for the Arctic Long Term Ecological Research Project at Toolik Lake, AK depicting sampling locations. Samples were collected from the shaded areas of phosphorus (CP), shade control (SC), shade + nitrogen and phosphorus (SNP), greenhouse controls (GC), greenhouse plus nitrogen and phosphorus (GNP), nitrogen (CN), control 1(C), and nitrogen and phosphorus (CNP).

\section{Sampling Sites Arctic LTER}
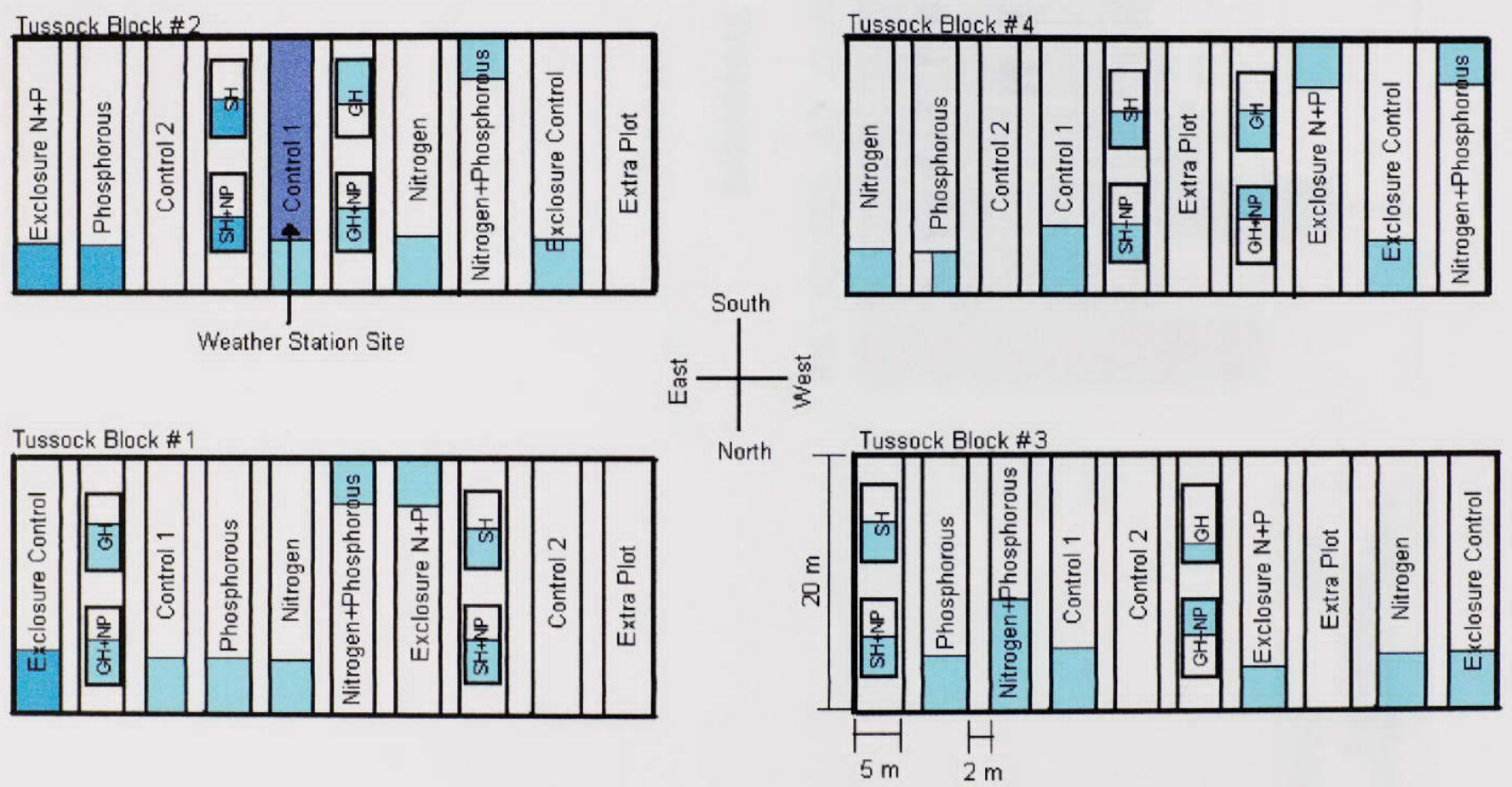
Figure 2. Average leaf size area and leaf-level light availability of Ledum palustre ssp decumbens by treatment $(\mathrm{C}=$ control, $\mathrm{GC}=\mathrm{Greenhouse}$ control, $\mathrm{GNP}=\mathrm{Greenhouse}+$ Nitrogen + Phosphorus, $\mathrm{CN}=$ Nitrogen, $\mathrm{CNP}=$ Nitrogen + Phosphorus, $\mathrm{CP}=\mathrm{Phosphorus,}$ $\mathrm{SC}=$ Shade control, $\mathrm{SNP}=$ Shade + Nitrogen + Phosphorus) Values are means $\pm \mathrm{SE}$. Color indicates average light level at the angel of the plant with red being lower light levels and blue higher light levels.

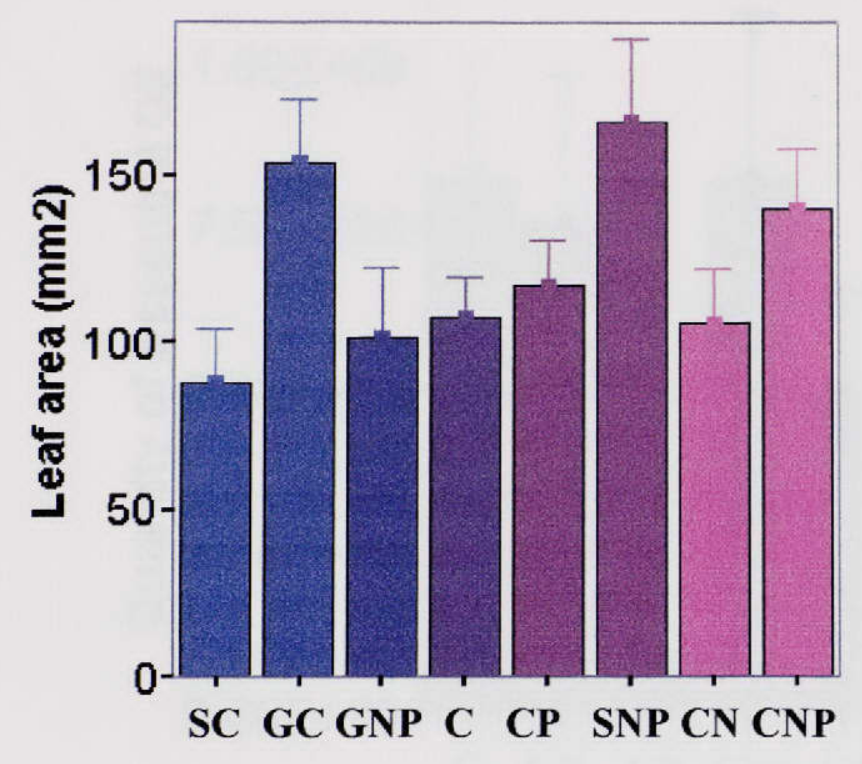

Light Level Means

157 2052

Treatment 
Figure 3. Total quantity of essential oil detectable in the headspace of samples of Ledum palustre $\mathrm{ssp}$ decumbens by treatment $(\mathrm{C}=\mathrm{Control}, \mathrm{CN}=$ Nitrogen, $\mathrm{CP}=\mathrm{Phosphorus}$, $\mathrm{CNP}=$ Nitrogen + Phosphorus, $\mathrm{GC}=$ Greenhouse control, GNP= Greenhouse + Nitrogen + Phosphorus, $\mathrm{SC}=$ Shade control, $\mathrm{SNP}=$ Shade + Nitrogen + Phosphorus). Bars represent means $\pm \mathrm{SE}$

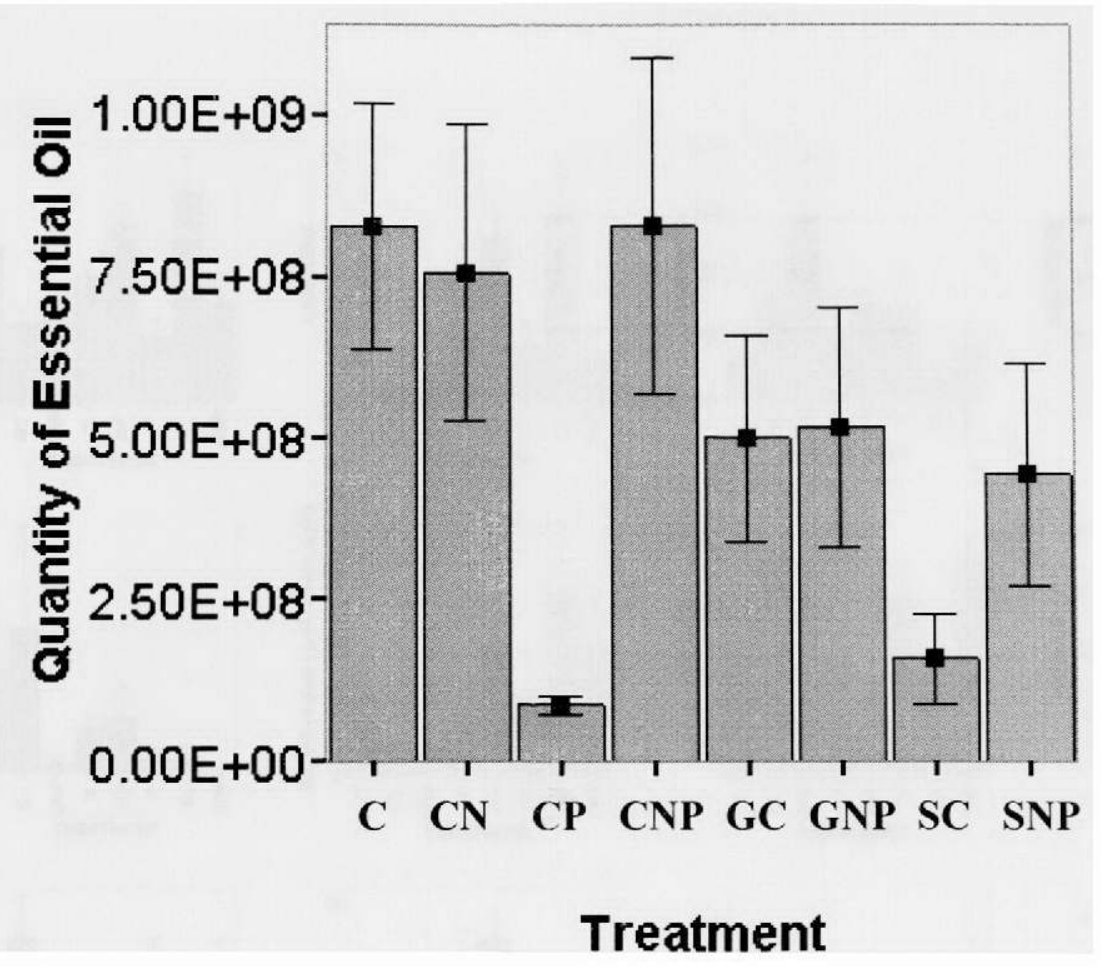


Figure 4. Percentage of each compound in the total essential oil of samples of Ledum palustre ssp decumbens by treatment (Alpha pinene, Camphene, Unknown 1, Beta pinene, Alpha phellandrene, allocymene, cymene, unknown 2, unknown 8, sabinene. unknown 3 , terpine-4-ol, unknown 5 , unknown 6 , and terpinene) by treatment $(\mathrm{C}=$ Control, $\mathrm{GC}=$ Greenhouse Control, $\mathrm{GNP}=$ Greenhouse plus nitrogen and phosphorus, $\mathrm{N}=$ $\mathrm{CN}=$ Nitrogen addition, $\mathrm{NP}=\mathrm{CNP}=$ Nitrogen and Phosphorus addition, $\mathrm{P}=\mathrm{CP}=$ Phosphorus addition, $\mathrm{SC}=$ Shade control, and $\mathrm{SNP}=$ Shade plus nitrogen and phosphorus). Bars are means $\pm \mathrm{SE}$.
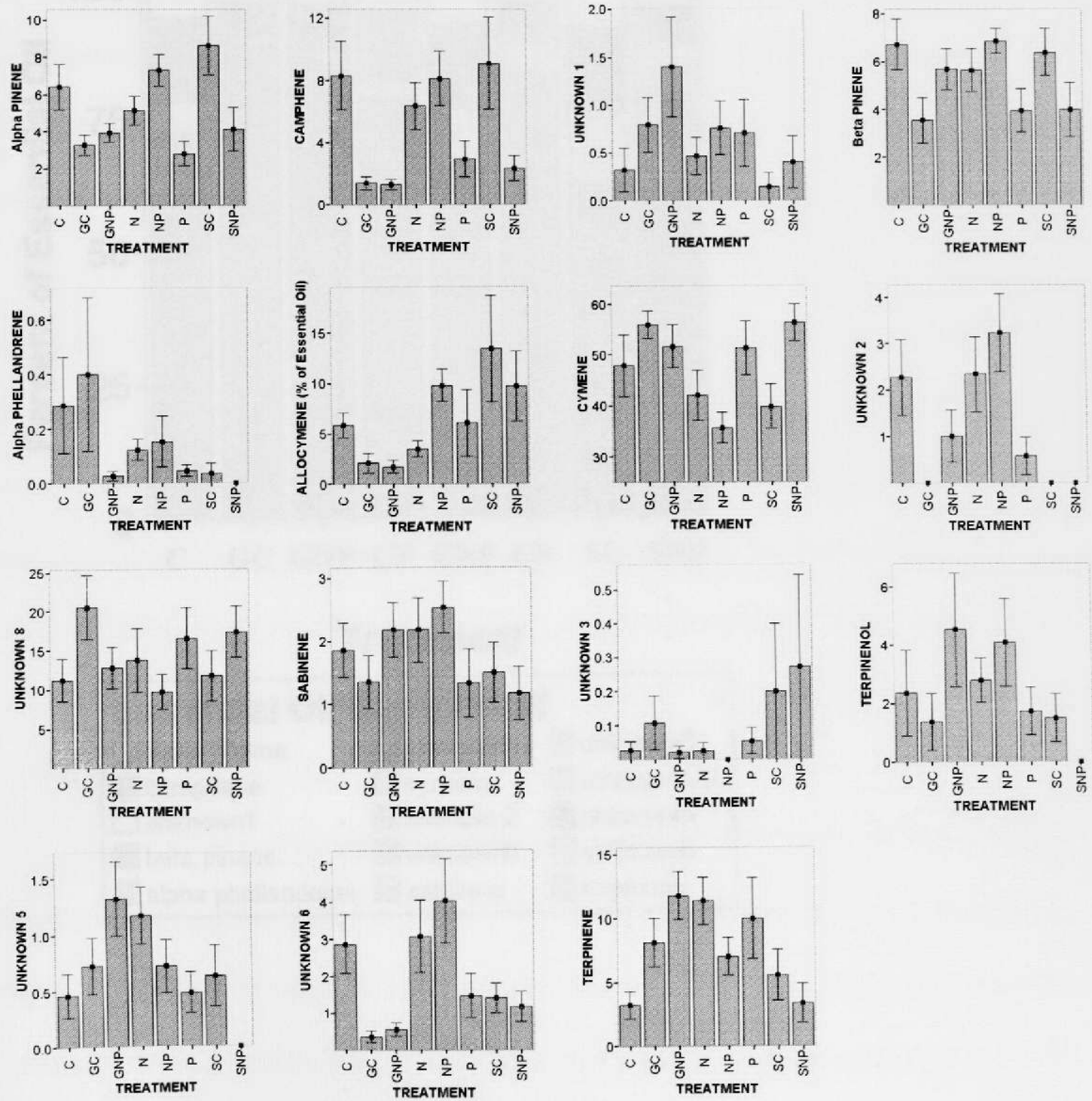
Figure 5. Representation of the relative percent of each compound in the essential oil of Ledum palustre ssp decumbens by treatment $(\mathrm{C}=\mathrm{Control}, \mathrm{GC}=$ Greenhouse Control, $\mathrm{GNP}=$ Greenhouse plus nitrogen and phosphorus, $\mathrm{CN}=$ Nitrogen addition, $\mathrm{NP}=$ Nitrogen and Phosphorus addition, $\mathrm{CP}=\mathrm{Phosphorus}$ addition, $\mathrm{SC}=$ Shade control, and $\mathrm{SNP}=$ Shade plus nitrogen and phosphorus). Bars are means.

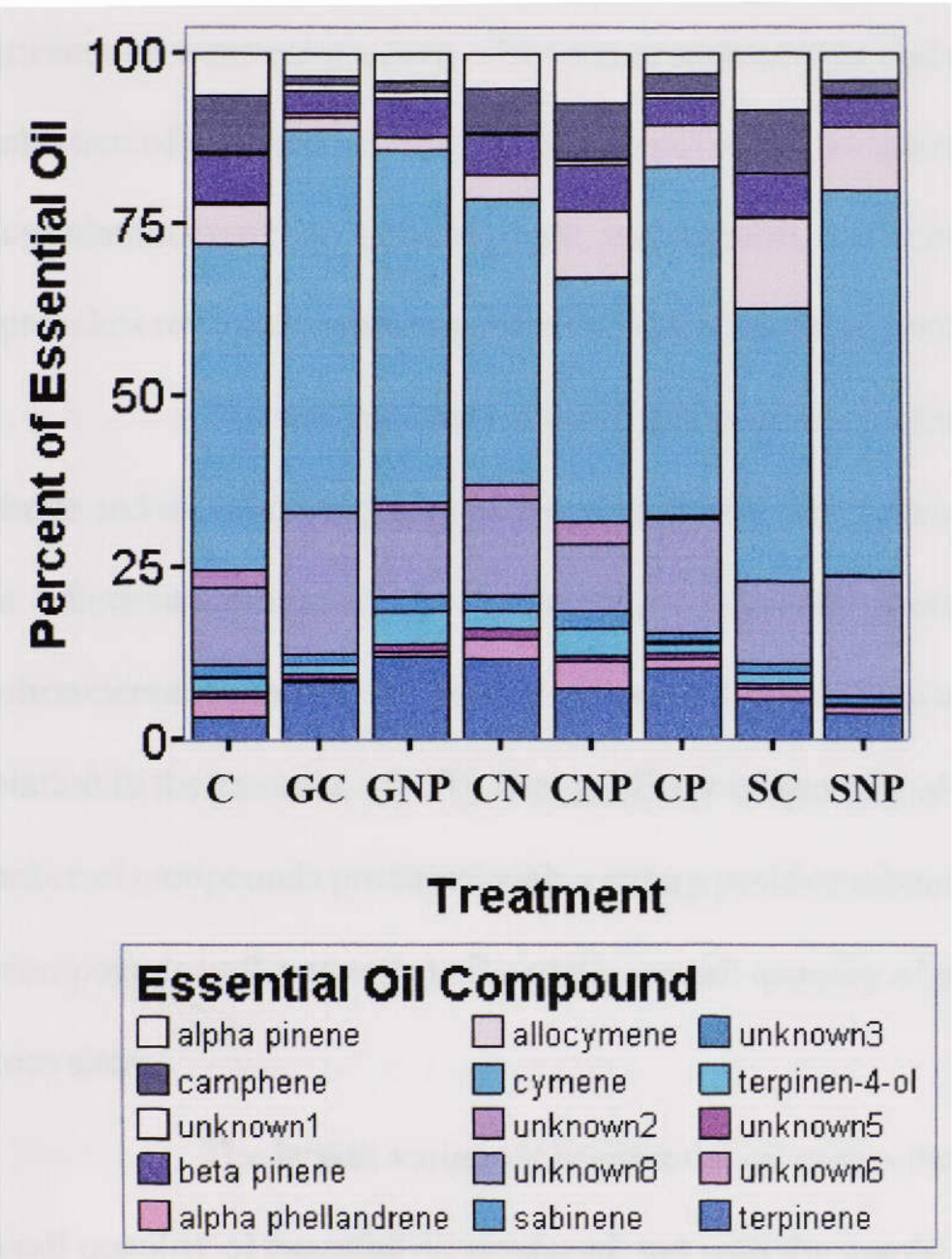




\section{Chapter IV}

\section{CONCLUSION}

The objective of my study was to evaluate the role of resource limitation on the essential oil production in Ledum palustre ssp decumbens. To meet this goal, 1 used two approaches: 1) evaluation of essential oils in Ledum across a latitudinal transect representing a natural gradient of resources such as light and temperature, and 2) evaluation of essential oils in Ledum in response to a long-term (14 yr) resource manipulation experiment altering light, temperature, and nutrients. The results of both approaches revealed complex patterns of essential oil production by Ledum.

The transect study showed that essential oil production varies based on latitude and elevation and time of growing season. The data suggest that this variation was influenced as much by the community in which the plants were found as by direct environmental variables, but neither of these influences was a strong predictor of the variation in the essential oil. The best predictor of quantity of essential oil was the number of compounds produced with a strong positive relationship between the number of compounds in the essential oil and the overall quantity of essential oil when compared across sites.

The largest variances in essential oil across the transect was not with the overall quantity of essential oil produced, but with the number of terpenoids expressed. Certain terpenes were expressed in some locations while not others, and as a result, the diversity of the essential oil ranged from 25 compounds at the most southern site to only 10 compounds at Toolik Lake, the $2^{\text {nd }}$ most northerly site and the site with the highest foliar nitrogen. 
The phenological stage of the plant has long been understood as an important influence on the production of essential oils, stemming from the fact that the essential oil is used as a means of protection and signaling. When vulnerable or valuable parts are produced, the essential oil composition changes to serve the needs of protection of that part or signaling for the appropriate visitor. This held true for L. palustre ssp decumbens as documented here. The essential oil varied in quantity and number of compounds as the phenological stage changed, with the biggest influence resulting from the presence or absence of specific compounds as the phenological stages change.

The relationship between the essential oil and the nutrients sequestered in the leaves was somewhat blurred due to complex community effects and temporal changes within the plant. However, on the scale of across the transect, the number of compounds and the quantity of essential oil was positively related to the leaf $\mathrm{C}: \mathrm{N}$ ratios, suggesting that where nitrogen was more limiting, more carbon was allocated into essential oils. No such relationship was found for phosphorus. Within sites, the relationships were more complex as a result of the seasonal changes in leaf nutrient concentrations with phenological stages. The flushing of leaves resulted in reversals of the directions of relationships among the essential oil and the foliar $\mathrm{C}: \mathrm{N}$ ratio and percent P. Since the terpenes in the essential oil of Ledum are volatile at relatively low temperatures, the temperature at the time of collection was also a potential confounding factor affecting the relationships.

The resource manipulation portion of this project was designed to tease apart those factors that might be the basis for patterns in the essential oil composition seen along the latitudinal transect, including light and nutrient availability and 
temperature. The resource manipulation of light, temperature and nutrients had complex effects on the quantity and quality of essential oil in the leaves. In contrast to the findings of the transect study, the number of compounds was not related to the total production of essential oil in the experimental manipulation. The most important factor for production of essential oils was reduced light, that reduced the number and total quantity of oils. Addition of $\mathrm{N}$ and $\mathrm{P}$ increased levels of those nutrients in plant tissues, but unexpectedly, there was not a clear correlation between leaf $\mathrm{N}$ and $\mathrm{P}$ and the number compounds or total quantity of essential oil terpenes. In contrast, large quantities and numbers of compounds were associated with low $\mathrm{N}$ levels for the cross-site comparison in the transect study. Furthermore, $\mathrm{N}$ and $\mathrm{P}$ additions alone tended to reduce the total quantity of essential oil; $\mathrm{P}$ addition caused a striking reduction in quantity of essential oil produced. However, $\mathrm{N}$ and $\mathrm{P}$ together did not affect production, as a result of a significant interaction between $\mathrm{N}$ and $\mathrm{P}$. These results suggest that the production of essential oils depends on the balance of both $\mathrm{N}$ and $\mathrm{P}$, a finding that explains the lack of relationships between essential oil production and individual nutrient components across the treatments. A somewhat unexpected finding was that increased temperature was not a significant factor. A complication in the interpretation of this study is that the long-term treatments resulted in large changes in plant community structure that undoubtedly had indirect effects on essential oil production, for example via shading by overtopping species and changes in the competitive balances for nutrients. The temperature manipulation might have had an adverse effect on the ability to detect the quantity of essential oil as the overall ambient temperature of the treatment was above the typical of natural communities. 
The :atitudinal transect portion of this study documented large variability in essential oil production by Ledum palustre ssp decumbens in response to natural environmental gradients and seasonal patterns. The experimental portion of the study showed that variation along the transect is likely a function of light level and $\mathrm{N}$ and $\mathrm{P}$ balances. The combination of the naturally occurring variation and the long-term resource manipulation suggests that in response to a changing climate, we can expect changes in plant community interactions involving these compounds and perhaps changes in the use of the plant by native peoples. 


\section{LITERATURE CITED}

Adams, R.P. and Hagerman, A. (1977) "Diurnal Variation in the volatile terpenoids of Juniperus scopulorum (Cupressaceae)". American Journal of Botany 64(3): 278285.

Belleau, F. and Collin G. (1993) "Composition of the essential oil of Ledum groenlandicum." Phytochemistry 33(1): 117-121.

Bigger, C.M. and Oechel, W.C. (1982) Nutrient effect on maximum photosynthetic rate in arctic plants. Holarctic Ecology 5(2), 158-163.

Boer, G.J., McFarlane, N.A., Blanchet, J.-P., and Lazare, M. (1990) "Greenhouse gasinduced climatic change simulated with the CCC second generation GCM. In "application of the Canadian Climate Centre General Circulation Model Output for Regional Climate Impact Studies: Guidelines for Users"(S.J. Cohen, ed.)pp.25. Atmospheric Environment Service, Canadian Climate Centre, Downsview, Ontario.

Bryant, J.P., Chapin III, F.S., Reichardt, P.B., Clausen, T (1985) "Adaption to resource availability as determinant of chemical defense strategies in woody plants." Recent Advances in Phytochemistry 19:219-237.

Bryant J.P (1987) "Feltleaf willow- snowshoe hare interactions: plant carbon- nutrient balance and floodplains succession." Ecology 68:1319-1327.

Calmes M.A. and Zasada JC. (1982). Some reproductive traits of four shrub species in the black spruce forest type of Alaska. Canadian Field-Naturalist 96: 35-40.

Chapin III, F. S. (1980). "Nutrient allocation and responses to defoliation in tundra plants." Arctic and Alpine Research 12(4): 553-564.

Chapin IIl, F. S. (1989) "The Cost of Tundra Plant Structures: Evaluation of Concepts and Currencies." American Naturalist 133(1): 1-19.

Chapin III, F.S., Shaver, G.R., Giblin, A.E., Nadelhoffer. K.J., Laundre. J.A. (1995). "Responses of arctic tundra to experimental and observed changes in climate." Ecology 76(3): 694-711.

Coley, P.D., Bryant, J.P., Chapin III, F.S. (1985) "Resource availability and plant antiherbivore defense." Science 230: 895-907.

Crane, W. J. B. and Banks, J. C. G. (1992) Accumulation and retranslocation of foliar nitrogen in fertilised and irrigated Pinus radiata. For. Ecol. Mgmt 52, 201-223. 
Dalgaard, V. and Fredskild, B (1993) Ledodendron tanhoeffeni (syn.: Rhododendron vanhoeffeni) refound in Greenland. Nordic Journal of Botany 13: 253-255.

Evstratova, R.I., Kabanov, V.S., Kryola, 1.L., Prokosheva, L.l. (1981) Khimiko Farmatsevticheskii Zhurnal. 12: 71.

Hamilton, J.G., A.R. Zangerl, E.H. DeLucia, and M.R. Berenbaum (2000). "The carbonnutrient balance hypothesis: Its rise and fall." Ecology Letters 4:86-95.

Hanover, J.W. (1966) Genetics of terpenes. I. Gene control of monoterpene levels in Pinus monticola DOUGL. Heredity, 21: 73-84.

Herms, D. A. and Mattson, W.J. (1992) "The Dilemma of Plants: To Grow or Defend." Quarterly Review of Biology 67(3): 283-335.

Houghton, J.T., Y. Ding, D.J. Griggs, M. Noguer, P.J. van der Linden and D. Xiaosu (Eds.). 2001. Climate change 2001: the scientific basis. Cambridge Univ. Press.

Hulten, E. (1968). Flora of Alaska and neighboring territories. Stanford, CA: Stanford University Press.

Inderjit, and Mallik, A.U. (1997) "Effects of Ledum groenlandicum amendments on soil characteristics and black spruce seedling growth." Plant Ecology 133: 29-36.

Karlin, E. F. and L.C. Bliss (1983) "Germination Ecology of Ledum groenlandicum and Ledum palustre spp decumbens." Arctic and Alpine Research 15(3): 397-404.

Keinanen, M. Julkunen-Tiitto, R., Mutikainen, P., Walls, M., Ovaska, J., Vapaavuori, E. (1999) Trade-offs in phenolic metabolism of silver birch: effects of fertilization, defoliation, and genotype. Ecology 80: 1920-1986.

Koricheva, J., Larsson, S., Haukioja, E., Keinanen, M. (1998) Regulation of woody plant secondary metabolism by resource availability: hypothesis testing by means if meta-analysis. Oikos 83: 212-226.

Kron and Judd (1990) Phylogenetic relationships within the Rhodoreae Ericaceae with specific comments on the placement of Ledum. Systematic Botany 15(1): 57-68.

Kudo, G. (1995). "Leaf traits and shoot performance of an evergreen shrub, Ledum palustre ssp decumbens, in accordance with latitudinal change." Canadian Journal of Botany-Revue Canadienne De Botanique 73(9): 1451-1456 
Larsson, S., Wiren, A. Lundgren, L., and Ericsson, T. (1986) "Effects of light and nutrient stress on leaf phenolic chemistry in Salix dasyclados and susceptibility to Galerucella lineola (Coleoptera)." Oikos 47: 205-210.

Lerdau, M. (1992) "Future discounts and resource allocation in plants." Functional Ecology 6:371-375.

Lerdau, M., Matson, P., Fall, R. Monson, R. (1995) "Ecological controls over monoterperene emissions from Douglas-Fir (Pseudotsuga menziesii)" Ecology 76 (8): 2640-2647.

Loomis, W.E. (1932) "Growth- differentiation balance vs. carbohydrate nitrogen ration." Proceedings of the American Society for Horticultural Science 29:240-245.

Lorio, P.L.jr. (1986) "Growth differentiation balance: a basis for understanding southern pine- beetle interactions." Forest Ecology Management 14: 259-273.

Marquis, R.J. (1992) Selective impact of herbivores. ln: Plant Resistance to Herbivores and Pathogens: Ecology, Evolution, and Genetics (eds R.S. Fritz and E.L. Simms). The University of Chicago Press, Chicago, IL, U.S.A., 301-325.

McCullough, D.G., Swenborg, P.D., Kulman, H.M. (1993) "Effects of nitrogen fertilization on monoterpenes of jack pine seedlings and weight gain of jack pine budworm (Lepidoptera: Tortricidae)" Great Lakes Entomologist 26 (2): 137-149.

McNulty, S.G. and Aber, J.D. (1993) Effects of chronic nitrogen additions on nitrogen cycling in a high- elevation spruce-fir stand. Candadian Journal of Forest Research 23(7): 1252-1263

Moorhead, D.L., Linkins, A.E., Everett, K.R. (1996) "Road dust alters extracellular enzyme activities in Tussock tundra soils, Alaska, USA." Arctic Alpine Research 28(3): 346-351.

Nadelhoffer, K.J., Shaver G.R., Giblin, A., Rastetter, E.B. (1997) "Potential impacts of climate change on nutrient cycling, decomposition, and productivity in arctic ecosystems." Global Change and Arctic Terrestrial Ecosystems: 349-364.

Powell, R.A., and Adams, R.P. (1973) "Seasonal variation in the volatile terpenoids of Juniperus scopulorum (Cupressaceae)." American Journal of Botany 60(10): 1041-1050.

Reichardt, P.B., Bryant, J.P., Anderson, B.J., Phillips, D., Clausen T.P., Meyer, M., Frisby, K. (1990) Germacrone defends Labrador Tea from browsing by snowshoe hare. Journal of Chemical Ecology 16(6): 1961-1976. 
Ruohomaki, K., Chapin, F.S.I., Haukioja, E., Neuvonen, S., and Suomela, J. (1996) Delayed inducible resistance in mountain birch in response to fertilization and shade. Ecology 77: 2302-2311.

Russels, K.P. Tanaina plantlore, an ethnobotany of the Dena'ina Indians of south Central Alaska. Alaska Natural History Association,1991.

Saville D.B.O.(1969) "Interrelationships of Ledum species and their rust parasites in Western Canada and Alaska." Canadian Journal of Botany 47: 1085-1100.

Shaver, G.R. (1983) "Mineral nutrition and leaf longevity in Ledum palustre; the role of individual nutrients and the timing of leaf mortality." Oecologia 56 (2-3): 160165.

Shaver, G.R., Canadell, J., Chapin Ill, F.S., Gurevitch J., Harte, J., Henry, G.,

Ineson, P., Jonasson, S., Melillo, J., Pitelka, L., and Rustad, L. (2000) "Global Warming and Terrestrial Ecosystems: A conceptual framework for analysis". Bioscience 50 (10): 871-882

Suzuki, S. and G. Kudo (1997) "Short term effects of simulated environmental change on phenology, leaf traits, and shoot growth of alpine plants on a temperate mountain in northern Japan." Global Change Biology 3: 108-115, suppl. 1.

Sveinbjornsson, B. (1992) "Arctic treeline in a changing climate" In: Arctic Ecosystems in a Changing Climate an ecological perspective (eds. Chapin llI, F.S., Jeffreis, R.L., Reynolds, J.F., Shaver, G.R., and Svoboda, J.). Academic Press, San Diego, CA. 239-253.

Tatro, V.E., Scora, R.W., Vasek, F.C., and Kumamoto, J. (1973) "Variation in the leaf oils of three species of Juniperus." American Journal of Botany 60: 236-241.

Tattje, D.H.E. and R. Bos (1981) "Composition of Essential Oil of Ledum palustre." Journal of Medicinal Plant Research 41: 303-307.

Walker, M. (1984) Harvesting the Northern Wild. The Northern Publishers.

Wilkens, R. T., and J.M. Spoerke. (1996) "Differential Responses of Growth and Two Soluble Phenolics of Tomato to Resource Availability." Ecology 77(1): 247-258.

Zangerl, A.R. (1986) Leaf value and optimal defense in Pastinaca sativa L. (Umbeliferae). American Midland Naturalist 116:432-436.

Zavala, J.A., and D.A. Ravetta (2001) "Allocation of photoassimilates to biomass, resin, and carbohydrates in Grindelia chiloensis as affected by light intensity." Field Crops Research 69: 143-149. 